\title{
Blockchain-Based IoT Devices in Supply Chain Management: A Systematic Literature Review
}

\author{
Muzammil Hussain ${ }^{1}{ }^{(D}$, Waheed Javed ${ }^{1}$, Owais Hakeem ${ }^{1}$, Abdullah Yousafzai ${ }^{1}$, Alisha Younas ${ }^{1}$, \\ Mazhar Javed Awan 2,*(D), Haitham Nobanee ${ }^{3,4,5, *}$ and Azlan Mohd Zain 6 (D) \\ 1 Department of Computer Science, University of Management and Technology, Lahore 54770, Pakistan; \\ muzammil.hussain@umt.edu.pk (M.H.); s2020279003@umt.edu.pk (W.J.); owais.hakeem@umt.edu.pk (O.H.); \\ abdullah.yousafzai@umt.edu.pk (A.Y.); alisha.younas@umt.edu.pk (A.Y.) \\ 2 Department of Software Engineering, University of Management and Technology, Lahore 54770, Pakistan \\ 3 College of Business, Abu Dhabi University, Abu Dhabi 59911, United Arab Emirates \\ 4 Oxford Centre for Islamic Studies, University of Oxford, Oxford OX3 0EE, UK \\ 5 Faculty of Humanities \& Social Sciences, University of Liverpool, Liverpool L69 7WZ, UK \\ 6 School of Computing, UTM Big Data Centre, Universiti Teknologi Malaysia, Skudai 81310, Malaysia; \\ azlanmz@utm.my \\ * Correspondence: mazhar.awan@umt.edu.pk (M.J.A.); haitham.nobanee@adu.ac.ae (H.N.)
}

check for

updates

Citation: Hussain, M.; Javed, W.;

Hakeem, O.; Yousafzai, A.;

Younas, A.; Awan, M.J.; Nobanee, H.;

Zain, A.M. Blockchain-Based IoT

Devices in Supply Chain

Management: A Systematic Literature

Review. Sustainability 2021, 13, 13646.

https://doi.org/10.3390/

su132413646

Academic Editor: Giada La Scalia

Received: 1 November 2021

Accepted: 3 December 2021

Published: 10 December 2021

Publisher's Note: MDPI stays neutral with regard to jurisdictional claims in published maps and institutional affiliations.

Copyright: (c) 2021 by the authors. Licensee MDPI, Basel, Switzerland. This article is an open access article distributed under the terms and conditions of the Creative Commons Attribution (CC BY) license (https:/ / creativecommons.org/licenses/by/ $4.0 /)$.

\begin{abstract}
Through recent progress, the forms of modern supply chains have evolved into complex networks. The supply chain management systems face a variety of challenges. These include lack of visibility of the upstream party (Provider) to the downstream party (Client); lack of flexibility in the face of sudden variations in demand and control of operating costs; lack of reliance on safety stakeholders; ineffective management of supply chain risks. Blockchain (BC) is used in the supply chain to overcome the growing demands for items. The Internet of Things (IoT) is a profoundly encouraging innovation that can help companies observe, track, and monitor products, activities, and processes within their respective value chain networks. Research establishments and logical gatherings are ceaselessly attempting to answer IoT gadgets in supply chain management. This paper presents orderly writing on and reviewing of Blockchain-based IoT advances and their current usage. We discuss the smart devices used in this system and which device is the most appropriate in the supply chain. This paper also looks at future examination themes in blockchain-based IoT, referred to as the executive's framework production network. The essential deliberate writing audit has been consolidated by surveying research articles circulated in highly reputable publications between 2016 and 2021. Lastly, current issues and challenges are present to provide researchers with promising future directions in IoT supply chain management systems.
\end{abstract}

Keywords: blockchain; internet of things; supply chain; devices; sustainability; supply chain management; operations; distributions

\section{Introduction}

A blockchain is a permanent record for recording transactions. It exists inside an appropriate system of unsecured nodes. Nodes can produce and read exchanges to use a consensus protocol to compose transactions in a block within the order. It has a list of blocks, each with an alternate size to store a rundown of trades. Hubs that participate in an agreement convention refer to gathering [1]. There are two classes of Blockchain: permissioned and public. In a public blockchain, anybody can inspect the chain's substance and check the validity of the data set aside [2].

Blockchain technology is not only used in bitcoin cryptocurrency but also in various domains such as smart cities [3], recommender systems [4], medical tourism [5], acceleration of energy efficiency [6], and information extraction [7].

Supply chain management (SCM) is a set of firms that pass material forward with declared steps [8]. Two or three available firms are secure for gathering a product and 
getting it to the end client. These make up an agile chain of material and section markers, product-building subject matter experts, wholesalers, retail carriers, and transportation affiliations, which are, for the most part, individuals from production organizations [9].

Traditional supply chain management systems face difficulties such as the absence of detectable quality from upstream to downstream, the absence of versatile responsiveness to unanticipated incidents and to cost control, the absence of partner trust relative to security, and an absence of cutting edge innovations [10]. A supply chain is a network that connects a company's suppliers to manufactures and distributes a particular product or services, and supply chain management is the management of products or services full manufacturing flows, from raw material to the delivery of the end product to the customer [11,12].

SCM requires the coordination of numerous gatherings, cycles, and resources. Therefore, the permission of Blockchain provides security, authenticity, and ownership to save time [13].

The Internet of Things (IoT) is widely known to clients. IoT is a group of interconnected devices that share data among users, for example, automation or monitoring. The data is shared in a private or public network [14]. The IoT can quickly help in malware detection and DDoS attacks in the network [15].

The combination of IoT and Blockchain provides an environment for easy transactions, security, lower cost, and expendable and reusable elements. Security is the primary concern for any industrial application through Blockchain [16].

Machine-learning-based approaches have also been successfully applied in medical sciences to diagnose various diseases [17-22]. Instruments of this sort can be used for continuous following and for alarms in checking temperature and moistness, providing excellent procedural chains for pharmaceuticals and food while incorporating ERP and supply chain solutions. Machine learning and Blockchain are used to solve security attacks in industrial IoT [23].

Blockchain-based IoT gives advantages to the supply chain: information progression and detectability; information accessibility; the link between information stream and material stream; and a decrease in implicit rules infringement and misrepresentation [24,25].

Our objective was to find current technical research topics, intelligent devices, and future exploration issues in Blockchain-based IoT related to supply chain management systems.

To our knowledge, there is no such study related to Blockchain IoT in terms of the supply chain. Blockchain-based IoT devices in the supply chain are the focus of this paper, structured as follows: In Section 2, we address a foundation of blockchain-based IoT instruments in the production network. Section 3 presents the exploration technique by characterizing research questions, consideration/avoidance measures, and search paths to gather compelling examinations applicable to the blockchain-based IoT gadgets in the inventory network area and zeroed in on various distribution stations. In Section 4, we present the exploration of the tables by orchestrating the chosen papers. Furthermore, the examination of some themes in IoT-based blockchain procedures for store networks, the board framework, sensors/gadgets, and future bearings are introduced in this part. Section 5 presents the conclusions of the article.

\section{Literature Review}

We discovered 14 investigations that looked into the condition of incorporating Blockchain with the IoT supply chain. The research, SLRs, and planning focuses of comparative themes are mentioned in Table 1. Ten of the papers focused on a single aspect of blockchain data management, specifically smart contracts and consensus protocols. One paper focuses on the plans' security properties, while the other focuses on estimating usage events. These related works are divided into five groups based on their centrality: security, smart contract, consensus, agreement estimation, use cases, and a Blockchain-based IoT applied in the supply chain.

Blockchain development is a publicly available report that allows completed trades to be recorded in blocks. With the addition or expansion of a new square, the chain of 
squares grows longer. Public key cryptography and appropriated understanding plans guarantee customers and insurance issues of IoT. In addition to cost ampleness, various Blockchain advancements in data security assurance join decentralization, indefinite quality, persistence, and suitability [26].

Blockchain innovation and IoT are disconnected advancements based on their unique methods of reasoning. The authors embraced a review of methods for incorporating these two trends into an innovative enterprise, focusing on securing decentralized design. The standard IoT strategy is insecure, and its implementations are vulnerable to threats to safety and security. Using collaborative planning to handle sensitive data opens the door to validation possibilities [27].

Once more, there are specific instances of unapproved access, unlawful use, and data offers. An epic degree relationship of IoT in applications is impossible. In any case, Blockchain development is expected to be at the forefront of IoT solution development. Blockchain progression's dependability and credits of infinite nature may be used to eliminate superficial security flaws in the IoT. Indeed, Blockchain progression's decentralization strategy property may be used to guide data and contraptions in stuff associations [28,29].

There are guarantees with Blockchain innovation in countering security shortcomings, expanding information honesty, and changing the way toward performing exchanges into a permanent, straightforward, and decentralized design. Further works need to develop security norms and dangers as bearings on square-based frameworks security [30].

Things produce information that is fundamental and delicate when it comes to stating details. IoT-based systems have recently been vulnerable to security threats and mechanized attacks, necessitating further research. The IoT's center points are low-controlled in most cases, with a lower cutoff for complex computational tasks. With the advancement of the Internet of Things, devices/center points should self-oversee essential functions within applications. Traditional security conventions are unsupportive of low-fueled IoT because of anticipated computational intricacy. Blockchain innovation can protect the IoT clients' security in a much-decentralized setting, as indicated by [31].

All in all, IoT gadgets have lesser computational abilities, gigantic security imperfections, and are exceptionally powerless to digital assaults. Customarily, IoT accumulates touchy individual data concerning their proprietors, which is halfway overseen by endeavors raising grave information trustworthiness and security issues. Blockchain runs a circulated record of exchanges whereby hubs arrive at a participatory agreement without an outsider's interruption and contribution. It limits the single purpose of disappointment and outsider trust [32].

The real IoT devices are arranged in weak spots, making them unprotected against developers. Upon this, there are high chances of changing the information broadcast across these associations. To be sure, endorsements of things and beginning information blend are significant concerns [33].

The IoT economy has begun sending sensors and things to perform cash-related trades as a compromise for organizations in a trustless circumstance, for instance, Machine-toMachine (M2M) and Peer-to-Peer (P2P). Following the improvement of 5G, a great deal of trades could successfully happen across an electronic association. It is advantageous for any sort of charging or portion structures for apportionment. Blockchain is a making Distributed Ledger Innovation (DLT) using a decentralized plan to engage strange, secure, and invariable trades. According to these, Blockchains could be an excellent game plan for IoT portions. Be that as it may, a couple of challenges prosper [34].

IoT advancement has become an integral part of people's day-to-day lives, especially enabling cycle monitoring and control. Smart devices have changed, implying that people's relationships with the natural world have also changed [35]. IoT is far from perfect, owing to apparent roadblocks and fundamental inadequacies that necessitate squeezing thinking. Blockchain advancement offers multi-faceted cycles and decentralized designing, which are huge for keeping an eye on an enormous number of the issues torturing IoT. 
Regardless, utilizing the Blockchain for IoT will require a veritable change to the substantial computational weights, delays, and movement speed of overheads of the past [36,37].

The recognized consuming Blockchain and Internet of Things (IoT) problems incorporate the accompanying: hefty asset uses of encoded hub information, unified engineering prompting the single purpose of disappointment impact, the synchronization of gadgets, the board of information volume produced, the similarity of the IoT, and Blockchain innovations. Nonetheless, sensor information put away on the Blockchain through exchanges could require lesser assets for shields because the Blockchain foundation is skilled in giving complete security answers for the whole IoT framework. Hypothetically, the Blockchainbased frameworks are less vulnerable to hazards due to their shared record approach for ensuring data [38].

They zeroed in on astute arrangement and declared that the joining of keen understanding and the IoT system could carry new game plans to the current structures and improve current working cycles [39]. The inspection of the particular understanding is being applied in IoT. Blockchain can energize various IoT circumstances summarized and explored in the examinations of [40]. The discussion use model and improvement pattern of an existing game plan on IoT interfacing blockchain give suggestions on updating a couple of points of view (system plan, cryptographic count, and message time venturing) of the current courses of action [41-45].

Traditional IoT data quality challenges are not resolved by using Blockchain in food supply chains [46]. A blockchain's data could simply be immutable rubbish. In response, the paper presents two solutions for data integrity and trust in the Blockchain and IoTenabled food supply chain [47].

The answers are to minimize the potential of arbitrary claims on IoT data performance and to encourage supply chain behaviors that increase the likelihood of desirable future states being realized through mechanism design [48-54].

Our proposed study addresses a deliberate composing review by coordinating an audit of Blockchain-based IoT progress and their current use topics in effortlessly chaining the board structure. We talk about the keen gadgets utilized in this framework and which gadget fits SCM. It likewise examines the future exploration themes in blockchain-based IoT alluded to as the executives' framework's flexible chain.

Table 1. Scope of related works.

\begin{tabular}{|c|c|c|c|c|c|}
\hline & $\begin{array}{l}\text { BlockChain/ IoT } \\
\text { SC Management }\end{array}$ & $\begin{array}{c}\text { Smart } \\
\text { Contracts }\end{array}$ & Consensus & Use Cases & Security \\
\hline $\begin{array}{l}\text { Survey/Reviews } \\
\text { SLR }\end{array}$ & $\begin{array}{c}{[24,32,40-42,47,55]} \\
{[40,55]}\end{array}$ & $\begin{array}{c}{[30,37,38,54]} \\
{[39]}\end{array}$ & {$[16,36,38,39]$} & {$[10,50,51]$} & $\begin{array}{c}{[33,34,43,49]} \\
{[35]}\end{array}$ \\
\hline
\end{tabular}

\section{Research Methodology}

Systematic Literature Review (SLR) has been selected for the study strategy for this paper. To the most fantastic aspect of our insight, no SLR has been published in the field of Blockchain-based IoT devices in the supply chain.

The SLR method in this article, as recommended by $[40,55]$. The technique used for this SLR is shown in Figure 1. 

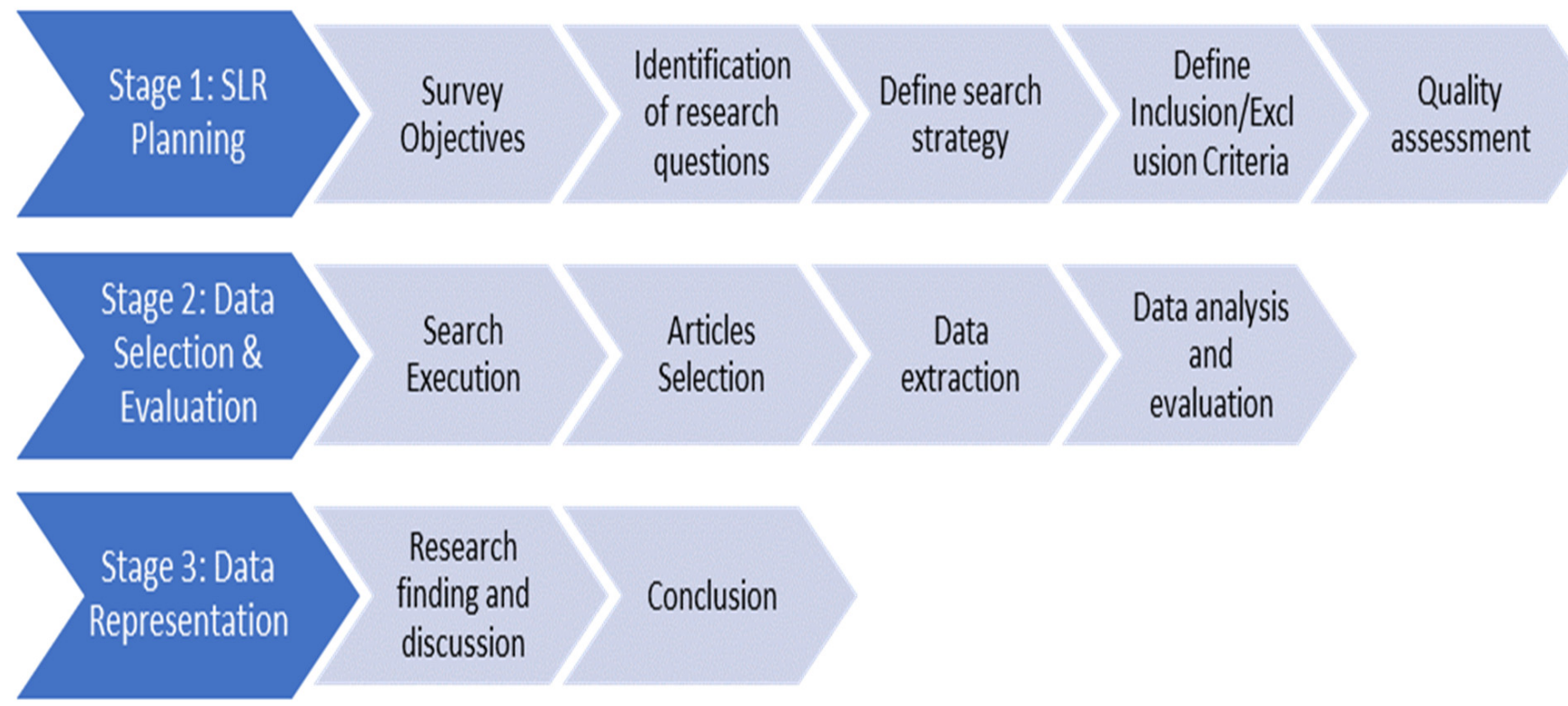

Figure 1. Systematic literature review process.

\subsection{Research Objective}

A comprehensive mapping study's primary goal is to provide an overview of research areas, the effects of IoT devices, favorable devices, and future directions in Blockchain IoT base supply chain Management:

$>$ To address IoT-based Blockchain techniques concerning Supply Chain Management;

$>$ To describe the effective use of Blockchain-based IoT devices in SCM;

$>$ To discuss the Blockchain-based IoT device is the most appropriate in SCM;

$>$ To address the future research directions in Blockchain-based IoT in SCM.

This paper wants to provide a comfortable environment for the researchers to see the publication frequencies with trends. The research procedure for this detailed planning study is shown in Figure 1.

\subsection{Research Questions}

The second stage of the systematic study is the definition of research questions. It is compulsory to write primary research questions. The research's main target is to overview research areas, favorable IoT devices, and future directions. This SLR contains five research questions in Table 2. These questions will enable us to categorize the existing research in Blockchain and the IoT-based supply chain and give us future domains for the research field.

Table 2. Research Questions.

\begin{tabular}{|c|c|c|}
\hline & Research Question & Major Purpose \\
\hline RQ1 & $\begin{array}{l}\text { What research topics have been addressed } \\
\text { in IoT-based Blockchain techniques } \\
\text { concerning Supply Chain Management? }\end{array}$ & $\begin{array}{l}\text { To identify which topics are discussed } \\
\text { in previous research papers. }\end{array}$ \\
\hline RQ2 & $\begin{array}{l}\text { How effective is the use of } \\
\text { Blockchain-based IoT devices in SCM? }\end{array}$ & $\begin{array}{l}\text { To investigate which devices were used } \\
\text { in the last documents. }\end{array}$ \\
\hline RQ3 & $\begin{array}{l}\text { Which Blockchain-based IoT device is the } \\
\text { most appropriate in SCM? }\end{array}$ & $\begin{array}{l}\text { To recognize the device's importance } \\
\text { relative to time. }\end{array}$ \\
\hline RQ4 & $\begin{array}{l}\text { What are the future research directions in } \\
\text { Blockchain used IoT in SCM? }\end{array}$ & $\begin{array}{l}\text { To identify current issues and challenges } \\
\text { for future research directions. }\end{array}$ \\
\hline
\end{tabular}




\subsection{Search Strategy}

These articles were retrieved from the following databases: IEEEXplore, ACM Digital Library, Science Direct, Springer Link, Wiley Online Library, Sage Journals, Taylor \& Francis Online, and also used Google Scholar to seek knowledge. The efficient use of Google Scholar is to find the bibliometrics for papers. The search strings used to find the results from the selected digital libraries appear in Table 3.

Table 3. Search strings for databases.

\begin{tabular}{cc}
\hline Database & Search Strings \\
\hline IEEE Xplore & $((($ "All Metadata": BlockChain) AND “All Metadata": IoT) \\
ACM Digital Library & AND “All Metadata": Supply Chain) \\
Science Direct & [All: Blockchain] AND [All: iot] AND [All: "supply chain"] \\
Springer Link & BlockChain AND IoT AND ("Supply Chain") \\
Wiley Online Library & 'BlockChain AND IoT AND ("Supply Chain")' \\
Sage Journals & "BlockChain AND IoT AND ("Supply Chain")" \\
Taylor \& Francis Online & [All Blockchain] AND [All iot] AND [All "supply chain"] \\
[All: Blockchain] AND [All: iot] AND [All: "supply chain"]
\end{tabular}

\subsection{Inclusion/Exclusion Criteria}

The fundamental goal of this part is to distinguish the most critical articles that add to our SLR. When the same articles appeared in research, they were to be considered as a single article. The first step that has been applied to the article is inclusion and exclusion criteria as described in Table 4.

Table 4. Inclusion/exclusion criteria.

\begin{tabular}{cc}
\hline Number & Inclusion Criteria \\
\hline IC1 & Papers that are focused on Blockchain, IoT-based supply chains \\
& Exclusion Criteria \\
EC1 & Papers do not include IoT \\
EC2 & Papers that are not focused on supply chain \\
EC3 & Papers discussing only Blockchain \\
\hline
\end{tabular}

\subsection{Quality Assessment}

The studies have been published in recognized and stable publication sources. To rate this answer, we need to consider the ranking of conferences, which will be CORE A, CORE $\mathrm{B}$, and CORE C. The journal ratings can be found using the Journal Citation Report (JCR). The possible answer to these questions has been explained in Tables 5 and 6 . Duplicate titles were removed. Which inclusion/exclusion criteria apply to any article depends upon the abstract. The reasonable response to these inquiries has been clarified in Table 5 .

Table 5. Quality criteria.

\begin{tabular}{ccc}
\hline Source & Grading & Rating \\
\hline Journal & $\mathrm{Q} 1$ & 2 \\
& $\mathrm{Q} 2$ & 1.5 \\
& $\mathrm{Q} 3$ & 1 \\
& $\mathrm{Q} 4$ & 0.5 \\
Conference, Workshop & If papers are not in JCR grading & 0 \\
& Core A & 2 \\
& Core B & 1.5 \\
& Core C & 1 \\
\hline
\end{tabular}


Table 6. Primary selection process for retrieved articles.

\begin{tabular}{|c|c|c|c|c|c|c|c|c|c|c|}
\hline $\begin{array}{l}\tilde{D} \\
\text { జే } \\
\omega \\
\omega\end{array}$ & 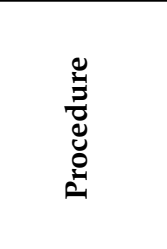 & 苞 & 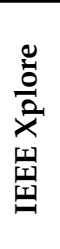 & 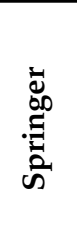 & 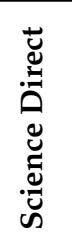 & 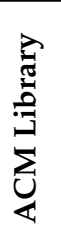 & 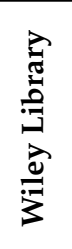 & 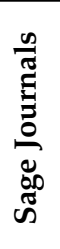 & 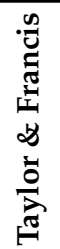 & $\underset{\mathfrak{0}}{\stackrel{7}{0}}$ \\
\hline 1 & Search & Keyword & 60 & 686 & 413 & 94 & 132 & 17 & 78 & 1480 \\
\hline 2 & Screening & Title & 32 & 41 & 45 & 25 & 5 & 0 & 10 & 158 \\
\hline 3 & Screening & Removal & 29 & 37 & 45 & 18 & 3 & 0 & 7 & 139 \\
\hline 4 & Screening & Abstract & 23 & 6 & 11 & 3 & 1 & 0 & 0 & 44 \\
\hline 5 & Inspection & Full Article & 23 & 6 & 11 & 3 & 1 & 0 & 0 & 44 \\
\hline
\end{tabular}

The papers do provide a contribution towards Blockchain IoT concerning supply chain management: "Yes $(+1)$ " or "No $(+0)$ ". The study presents a straightforward solution to the problem in Blockchain IoT concerning the supply chain. The possible answer was "Yes (+1)", "Partially (+0.5)" and "No $(+0)$ ".

Different articles have referred to the distributed investigations. The questions have the following answers:

(a) If there is no citation, then the answer will be "No $(0)^{\text {"; }}$;

(b) If citation count is between 1 to 5 , then the answer will be "Partially $(+0.5)$ ";

(c) If citation count is more than five, then the answer will be "Yes $(+1)$ ".

The ratio of journal to conference papers is shown in Figure 2 in the form of a pie chart. Appendix $\mathrm{A}$ is about the classification with a quality evaluation score.

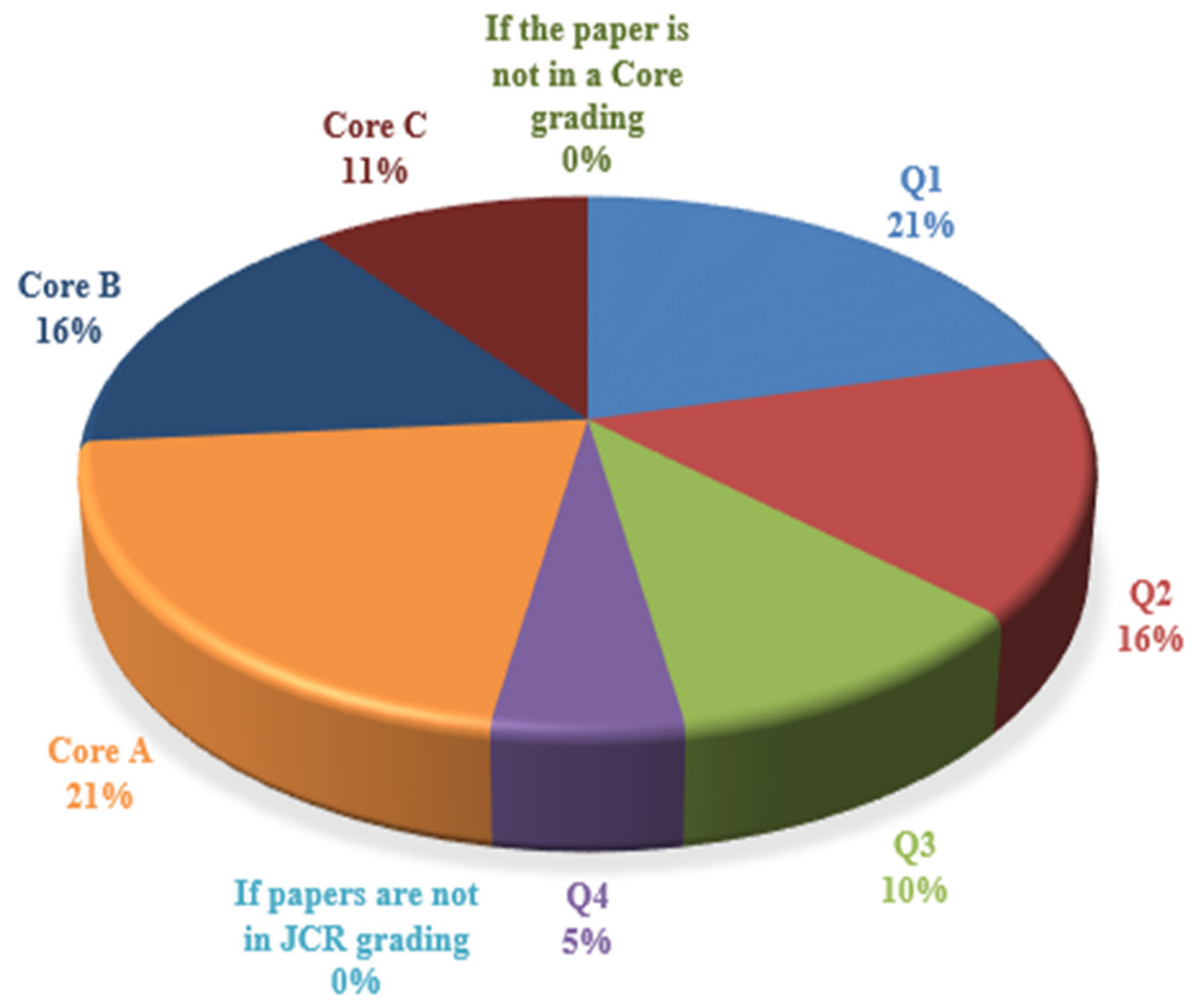

Figure 2. Quality criteria of journals and conferences paper pie chart. 


\subsection{Study Selection Process}

Table 6 shows the option and search steps applied on chosen vaults to obtain 1480 outcomes. A screening interaction has been applied based on the rejection rules, catchphrases, titles, edited compositions, and complete articles of recovered papers. In this way, we chose 158 papers. We dispensed with the duplicate titles and the titles that do not apply to this examination from that point onward. In addition to examining the completely changed works of the picked 139 papers in the duplication stage, we have picked 44 depending on their altered creations. At last, 44 examinations were picked out of 1480.

Figure 3 shows the bar chart of the number of publications against the research databases counts.

\section{Publication Sources}

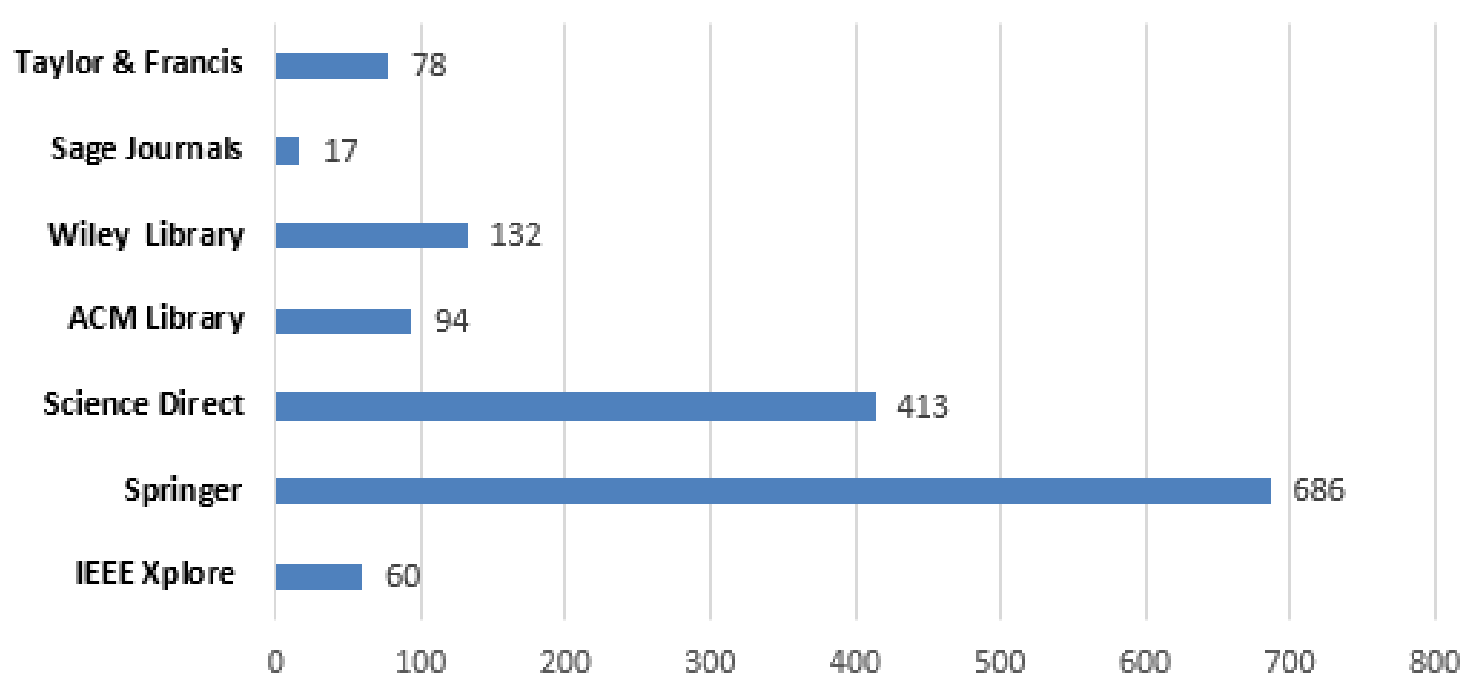

Figure 3. The primary selection process for retrieved articles.

\section{Results and Discussion}

In this segment, the discoveries identified with the SLR addresses introduced in Table 8 are portrayed. Following the screening period's selection, examination concentrates used to outline each exploration question answer to make a fundamental commitment to the Blockchain-based IoT store network area. The data extraction scheme provides a game plan of possible responses to the research questions.

4.1. RQ1. What Have Research Topics Addressed in IoT-Based Blockchain Techniques Concerning Supply Chain Management?

\subsubsection{Pharmaceutical Industry}

In a traditional pharmaceutical supply chain, they come to face challenges of wellbeing, trust, shortcoming, traceability, and invisibility of pharmaceutical products and devices in the supply chain. However, the IoT devices such as radio frequency identification (RFID), sensors, locators, and QR codes remove all these problems. Simultaneously, with the assistance of Blockchain-dispersed record innovation, the information is straightforward and detectable, and the information is not altered, offered, or stored at each connection of the supply chain. The Blockchain provides privacy and the personal requirement for valuable data [56-60].

\subsubsection{Food Supply Chain}

The food chain with a discernibility framework has been set up with enhanced features. The system uses IoT devices to track and trace items to collect data and update each 
product's movement. There are two algorithms, Hyperledger Sawtooth and Ethereum, primarily used in the food supply chain. In some cases, Ethereum has high latency of scalability and reliability, and it also represents a barrier for computationally limited devices. Hyperledger Sawtooth is suitable for tiny devices. The Blockchain applies to supply chain management based on IoT devices for traceability and provides security, timely data delivery, and efficient multi-hopping in a low-cost implementation. Many architectures proposed in different papers use Oracle's network, smart contracts, and the lightweight consensus for IoT (LC4IoT) protocol for IoT sensor devices, especially RFID, etc., [61-69].The details domain-wise of the publications are described in Table 7.

Table 7. Publications' research topics.

\begin{tabular}{cc}
\hline Research Topics & Reference \\
\hline Pharmaceutical Industry & {$[56-60]$} \\
Food Supply Chain & {$[61-69]$} \\
Healthcare, Automotive, Manufacturing & {$[70-75]$} \\
Humanitarian Aid & {$[76-79]$} \\
Government Sectors & {$[80,81]$} \\
Applications in Shipping, Transportation, Logistics & {$[82-88]$} \\
Industrial and Academic Area & {$[89-94]$} \\
Authenticity and Cyber Security & {$[34,90,92-94]$} \\
\hline
\end{tabular}

\subsubsection{Healthcare}

Blockchain innovation can change over the IoT, and the medical services supply chain the executives by its eccentric component's ethical quality. Blockchain innovation features momentum requests and distinguishes potential exploration holes that could profit the business [70-72].

\subsubsection{Automotive}

Blockchains make the supply chain resilient using a smart contract, genuinely dispersed shared frameworks, and furnishes the capacity to cooperate with peers in a trusted, auditable way. The assembling plant has fundamental needs of conveyance of parts gracefully at the perfect season of insect outsider coordination, transportation organizations, multipliers, etc. The contraptions in the IoT climate give a second territory and material permission to the real things in the production network that are for the most part confined through fake news [73-75].

\subsubsection{Humanitarian Aid}

The scrutinized cover is related to disseminating and disseminating blockchain-based shrewd agreements in the compassionate segment. The improved transparency of any technology automatically increases time and cost. A few obstructions to embracing innovation in compassionate guide supply chains are isolated into authoritative, mechanical, and natural.

The hierarchical obstruction comprises obliged money-related assets, deficient help and duty from the board, and the requirement for fundamental changes in measures.

The technological barrier consists of four obstacles: immaturity of the technology, unwieldy prerequisites, deficient framework in calamities, and the immutability of the transactions.

The natural hindrance included guideline issues, barely any pilots in the division, various orders, standards, and targets.

Blockchain and the IoT offer many chances for versatility and security under a costadequacy viewpoint. Subsequently, the lifesaving and rebuilding of everyday environments passed to the fiasco [76-79]. 


\subsubsection{Government Sectors}

Electronic government (e-government) constructs administrations around residents and occupants makes taxpayer-driven organizations more reachable, ingests social perspectives, shares data, and uses assets adequately. Governments have an incredible enthusiasm for actualizing and improving their e-taxpayer driven organizations by adopting blockchain technology. Blockchain technology provides security and defeats limitations and improves running services. The United Arab Emirates (UAE) has also made progress in establishing a Global Blockchain Council to promote blockchain use among its organizations, such as the e-greater part manages framework, and so on.

The first and most extensive approved blockchain network is now working in different activities, supporting e-government and applications in the European Network $[80,81]$.

\subsubsection{Applications}

Since IoT innovation considers the creation and usage of utilizations in an ongoing observing climate, it is expected that 50 billion gadgets will be associated by 2020 . A few applications, such as protection, inventory network frameworks, shrewd urban communities, and keen vehicles, now work with IoT gadgets. Nevertheless, the external user's trust is the main issue; the architectonics of any application can be a centralized or decentralized system. The decentralized system provides trust, stores digital transactions, and provides authentication through hashing and digital signature [82-84].

\subsubsection{Logistics}

Logistics are the implementation phase of complex operations in any organization. The smart contract is a prominent part of the business logic and is amalgamated by Blockchain architectonics. A smart contract is an autorun program activated by tags, IoT sensors, actuators, etc. [85-88].

\subsubsection{Industrial and Academic Area}

Blockchain in 5G-empowered IoT gadgets of conversation is isolated into three sections: the foundation of Blockchain, IoT, and individual modern 5G applications. The Blockchain maintains security and faster data flow in industrial and academic areas. The essential of this innovation is a circulated stockpiling framework dependent on cryptography and agreement calculations. Presently, numerous applications were executed in finance, horticulture, payment, and medication territory. This blockchain technology application is used in air traffic controllers (ATCs) to lessen fracture, failure, and ungraceful activities in the air terminal industry [89-94].

\subsubsection{Authenticity and Cyber Security}

Network modernization has expanded the arrangement of savvy web-associated energy innovation conceivably defenseless against digital dangers. Obtaining these gadgets and acknowledging new NERC CIP consistency prerequisites keeps testing energy utilities, particularly associations that do not have the essential assets. Inventive arrangements were required because of these complex and advancing digital difficulties. This paper investigated other freedoms and difficulties in applying Blockchain-circulated record innovation to improve and obtain the intricate programming and equipment store network that makes up current energy utilities [95-99].

\subsection{RQ2. How Effective Is the Use of Blockchain-Based IoT Devices in SCM?}

The devices are dumb if human beings cannot involve them in communicating realtime data. Human beings use devices, the IoT makes the small world around us more modifiable and reactive to integrating the electronic and corporeal universe. Nevertheless, the IoT has some security and privacy challenges which can be overcome by merging blockchain technology. 
The Blockchain system protects data integrated into the billions of corporeal devices worldwide. The devices are connected by the Internet and share data using a secure Blockchain structure. Blockchain-based IoT devices have transformed SCM. They progressively follow the area of merchandise, amount, and other helpful data, improving assembling plants, arranging a creation plan, and improving material and data stream frameworks [100,101].

In practice, there are a few global positioning frameworks accessible through GPS (Global Positioning System), RFID (Radio-Frequency identification), Barcode Readers, QR code Reader, Temperature Sensors, Healthcare Data Gateway (HGD), Electronic Medical Record (EMR) systems, GPS tags and chips and mobile phones, the web of IoT sensors, wireless-enabled devices, Wireless Sensors, HACCPs (Hazard Analysis and Critical Control Points), and Near Field Communication (NFC) [64,102-118].

Figure 4 shows the ratio of papers related to IoT devices.

\section{Devices used in papers}

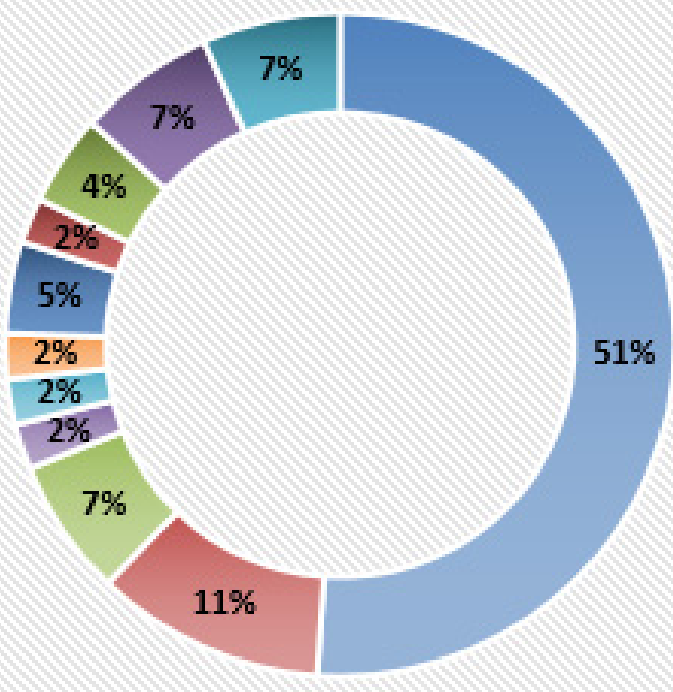

- RFID (Radio-Frequency identification)

- Barcode Reader

- $\mathrm{QR}$ code Reader

- Temperature Sensors

- Healthcare Data Gateway (HGD)

- Electronic Medical Record (EMR) systems

- GPS tags and chips and mobile phone

- web of loT sensors

- wireless-enabled devices/Wireless

Sensor

Figure 4. Comparison of IoT devices in research literature.

4.3. RQ3. Which Blockchain-Based IoT Device Is the Most Appropriate in SCM?

The most appropriate device used in Blockchain base SCM is RFID (Radio-frequency identification) to use radiofrequency waves to track the items. There are two techniques to perform functions of RFID, i.e., Transmitter and Receiver.

Table 8 shows that there are many devices to read about in the literature, but the highest ranking device used in many papers is radio frequency identification (RFID). 
Table 8. Present research on devices in the literature review.

\begin{tabular}{|c|c|}
\hline Infirmity & Sensor/Devices Operations \\
\hline $\begin{array}{l}\text { RFID (Radio-Frequency } \\
\text { identification) }\end{array}$ & $\begin{array}{l}\text { RFID gives the personal ID of labels to follow the item and take it } \\
\text { essential information, which helps in continuously observing. The } \\
\text { well-known RFID gadget, which utilizes a } 900 \text { MHZ recurrence } \\
\text { coordinated sensor, was exemplified for continuous sensor } \\
\text { information accession [103]. }\end{array}$ \\
\hline Barcode Reader & $\begin{array}{l}\text { Barcode Reader is assisting with mechanizing information } \\
\text { assortment, preparing, and approval. This information will be put } \\
\text { away on the edge gadget in squares secured consecutively (time } \\
\text { course of action), and afterward will be sent to the cloud [104]. }\end{array}$ \\
\hline QR code Reader & $\begin{array}{l}\text { QR code is a mobile-based application that identifies the details of the } \\
\text { product. This is global recognition of "items" detail. A QR code is } \\
\text { similar to an RFID device but differs in size [105]. }\end{array}$ \\
\hline Temperature Sensors & $\begin{array}{l}\text { The temperature sensor contraption checks the temperature of the } \\
\text { enveloping of decayable products. Especially, RFID temperature } \\
\text { sensors self-tune between } 902 \mathrm{MHz} \text { and } 928 \mathrm{MHz} \text {, working in the } \\
\text { RFID UHF band, as the temperature rises up or drops out a particular } \\
\text { doorstep }[106,107] \text {. }\end{array}$ \\
\hline $\begin{array}{l}\text { Healthcare Data } \\
\text { Gateway (HGD) }\end{array}$ & $\begin{array}{l}\text { Healthcare Data Gateway (HGD) depends on progressively } \\
\text { comprehensive security to reach the patients of data to empower the } \\
\text { patient to claim information effectively controlled and offer to a } \\
\text { concerned specialist. HGDs are more controlled than Medical }\end{array}$ \\
\hline $\begin{array}{l}\text { Electronic Medical } \\
\text { Record (EMR) systems }\end{array}$ & $\begin{array}{l}\text { Records as they depend on progressively severe security [108-110]. } \\
\text { Electronic Medical Record (EMR) is the patient record that } \\
\text { persistently screens the patient and checks the doctor's medication } \\
\text { portion suggestion, particularly the patient with coronary illness and } \\
\text { disease. These clinical records exhibit to be an excellent assistance for } \\
\text { patients and the concerned specialist. These clinical records need } \\
\text { greater security and protection to restrict the break and abuse of } \\
\text { information [111,112]. }\end{array}$ \\
\hline $\begin{array}{l}\text { GPS tags and chips and } \\
\text { mobile phones }\end{array}$ & $\begin{array}{l}\text { An analysis of actual noteworthiness usage reveals that such a } \\
\text { tracker, operated by a single coin cell, is compelled by the breaking } \\
\text { point's size about the reported signs rather than the centrality use. } \\
\text { The pre-owned } 2 \mathrm{~Gb} \text { streak putting away can store } 65,600 \\
\text { 1-millisecond sign depictions. This equates to } 683 \text { days of } \\
\text { quarter-hourly orchestration. Our model GPS tracker weighs just } \\
1.3 \mathrm{~g} \text { and has } 23 \times 14 \mathrm{~mm} \text { measurements. This allows it to be } \\
\text { concealed for weight-sensitive applications such as fowl tracking and } \\
\text { links it to very critical items such as wallets, sacks, or bikes [113]. }\end{array}$ \\
\hline Web of IoT Sensors & $\begin{array}{l}\text { The advancements create constant information streams and have a } \\
\text { few attributes: (1) high-speed absorb memory data storage, (2) } \\
\text { distributed architecture scalability. (3) real-time query interactive } \\
\text { data, etc. A buffering framework controls the information stream and } \\
\text { guarantees continuous presentation between the information maker } \\
\text { and the information buyer [114,115]. }\end{array}$ \\
\hline $\begin{array}{c}\text { Wireless enabled } \\
\text { devices/Wireless Sensor }\end{array}$ & $\begin{array}{l}\text { Wireless Sensor Networks (WSNs) give the "cells" for information } \\
\text { assortment and circulation of IoT empowered gadgets and setting } \\
\text { mindful applications for sharing various sorts of intensity sources } \\
\text { and keeping up power self-governance for enormous periods, these } \\
\text { gadgets sharing and making sure of the information in the } \\
\text { network [116,117]. }\end{array}$ \\
\hline $\begin{array}{l}\text { HACCP (Hazard } \\
\text { Analysis and Critical } \\
\text { Control Points) }\end{array}$ & $\begin{array}{l}\text { Hazard Analysis and Critical Control Points (HACCP) give a } \\
\text { detectability and security framework to the food gracefully chain } \\
\text { centers around straightforward [64]. }\end{array}$ \\
\hline $\begin{array}{l}\text { NFC (Near Field } \\
\text { communication) }\end{array}$ & $\begin{array}{l}\text { Near Field Communication (NFC) are gadgets that obtain completely } \\
\text { clear and ongoing data to produce legitimately on the related office, } \\
\text { permitting constancy using a robust, cloud-based database [118]. }\end{array}$ \\
\hline
\end{tabular}


The tags are also used in this system to transmit signals of id systematically. The tag attaches with items, and every tag has a frequency band for signaling between the Transmitter and Receiver.

The sensory system tracks and monitors of the items at various retailers, coordinations, or capacity stages inside the supply chain, and information is refreshed in a Blockchain framework. The related persons check the record book to acquire the information concerning the specific item.

Integrating Blockchain, RFID-based SCM provides towering data protection, glassiness, trustworthiness, and management costs compared with the conventional decentralized database system. This is a secure method for communication with the RFID tags of items with Blockchain nodes.

\section{Future Work and Limitations}

\section{RQ4. What Are the Future Research Topics in Blockchain Used IOT Based SCM?}

Blockchain-based IoT in SCM as a future research direction is not comprehensible, but fitter away time mainly notion and orchestrations understandable and move to the work. On the other hand, the extension of hardware architecture under the suitable proposed framework for implementations comprising real IoT gadgets and gateways will obtain the highest performances in the future for different industries prospective of big data [119-127].

The correlation and examination between the two engineering to investigate the edge's presentation gains as far as idleness, I/O, CPU, IoT gadgets utilization, and Blockchain processing cost and to find efficiency in results for the future.

Our study's limitations are that the Blockchain intelligent contracts certify the correctness of transaction data in supply chain management through IoT not appropriately addressed. Secondly, the modern times' advancement of technology, security, and challenges are the main topics of future research direction because, with time, security requirements are towering and face unalike challenges, for example, traceability, data provenance, and cyber-attacks.

Lowering CPU requirements to operate blockchain code on moderate IoT smart objects and building fault tolerance in the interchange between devices and networks are two aspects of deployment. Another area of investigation will involve lightweight network protocols for device-to-device communication infrastructure propagation and algorithms for achieving network consensus.

In future work, recently, the deep learning models [128-135] inspired through images have performed good results. We could use the literature of IoT solutions of supply chain images with the help of convolutional neural networks and other models.

The strategy entails creating an architecture for an intelligent contract management framework for logistics and implementing an adaptable yet straightforward system for testing fundamental logistics activities.

\section{Conclusions}

This paper presented an orderly composing review that presents a conversation on unequivocal high-quality research articles passed on in the space of Blockchain-based IoT, suggesting inventory networks to the executives. Our SLR screened 44 potential papers. These are detailed analyses of research topics, future research topics, and IoT smart devices and also discuss the most appropriate devices in terms of supply chains.

Author Contributions: All authors contributed equally to this work; Conceptualization, M.H. and A.M.Z.; formal analysis, W.J. and M.J.A.; funding acquisition, H.N. and A.M.Z.; investigation, W.J. and M.J.A.; methodology, O.H. and A.Y. (Alisha Younas); supervision, M.H. and A.Y. (Abdullah Yousafzai); writing-original draft, W.J., O.H. and A.Y. (Alisha Younas); writing-review and editing, O.H., A.Y. (Alisha Younas) and M.J.A. All authors have read and agreed to the published version of the manuscript.

Funding: This research received no external funding. 
Institutional Review Board Statement: Not applicable.

Informed Consent Statement: Not applicable.

Data Availability Statement: Not applicable.

Conflicts of Interest: The authors declare no conflict of interest.

\section{Appendix A}

Table A1. Classification and Quality Evaluation Score.

\begin{tabular}{|c|c|c|c|c|c|c|c|c|c|c|}
\hline Reference & Year & P. Channel & $\begin{array}{c}\text { Method of } \\
\text { Investigating }\end{array}$ & Primary Focus & Gadgets & $\mathbf{a}$ & $\mathbf{b}$ & c & d & Score \\
\hline [10] & 2019 & Conference & Framework & $\begin{array}{l}\text { Solutions provided to those } \\
\text { problems of industries with } \\
\text { Blockchain IoT-based } \\
\text { supply chain }\end{array}$ & $\begin{array}{l}\text { IoT Sensor and } \\
\text { Devices }\end{array}$ & 1 & 1 & 1 & 0 & 3 \\
\hline [103] & 2019 & Conference & Tool & $\begin{array}{l}\text { To improve recognizability } \\
\text { in the } \\
\text { pharmaceutical supply } \\
\text { chain utilizing IoT edge } \\
\text { gadgets and Blockchain. }\end{array}$ & $\begin{array}{l}\text { IoT Sensor and } \\
\text { Devices, RFID, } \\
\text { barcode, GPS tracker, } \\
\text { Temperature sensor }\end{array}$ & 1 & 1 & 0 & 0 & 2 \\
\hline [101] & 2019 & Conference & Model & $\begin{array}{c}\text { Summarized the issues of } \\
\text { the delivery model }\end{array}$ & $\begin{array}{c}\text { IoT Sensor and } \\
\text { Devices, RFID }\end{array}$ & 1 & 1 & 0 & 0 & 2 \\
\hline [68] & 2019 & Conference & Architecture & $\begin{array}{l}\text { The utilization of a } \\
\text { protected IoT (BC) } \\
\text { engineering for a food } \\
\text { inventory network's usage } \\
\text { occasion was depicted. }\end{array}$ & $\begin{array}{l}\text { IoT Sensor } \\
\text { and Devices }\end{array}$ & 1 & 1 & 0.5 & 0 & 2.5 \\
\hline [59] & 2020 & Conference & Tool & $\begin{array}{l}\text { Blockchain and RFID are } \\
\text { utilized in the drug supply } \\
\text { chain to improve the } \\
\text { recognizability and } \\
\text { permeability of } \\
\text { medications. }\end{array}$ & RFID & 1 & 1 & 0 & 0 & 2 \\
\hline [55] & 2019 & Article & $\begin{array}{l}\text { Proposed } \\
\text { System }\end{array}$ & $\begin{array}{l}\text { Proposed to incorporate } \\
\text { fluffy rationale into the } \\
\text { absolute detectability } \\
\text { period of usability of the } \\
\text { executives' framework }\end{array}$ & $\begin{array}{l}\text { IoT Sensor } \\
\text { and Devices }\end{array}$ & 1 & 1 & 1 & 2 & 5 \\
\hline$[62]$ & 2019 & Conference & $\begin{array}{l}\text { Proposed } \\
\text { System }\end{array}$ & $\begin{array}{l}\text { The following framework } \\
\text { with the utilization of IoT } \\
\text { devices and store } \\
\text { information and dealing } \\
\text { with each node of data }\end{array}$ & $\begin{array}{l}\text { RFID, Barcode, } \\
\text { QR code }\end{array}$ & 1 & 1 & 0.5 & 0 & 2.5 \\
\hline [63] & 2018 & Conference & Implementation & $\begin{array}{l}\text { Tracking and tracing } \\
\text { system in agriculture } \\
\text { food-chain system }\end{array}$ & $\begin{array}{l}\text { RFID, IoT sensor and } \\
\text { devices, NFC devices, } \\
\text { HACCP }\end{array}$ & 1 & 0.5 & & 0 & 2.5 \\
\hline [77] & 2019 & Conference & Guideline & $\begin{array}{l}\text { The idea of complementary } \\
\text { technologies for complete } \\
\text { digitization of supply chain }\end{array}$ & $\begin{array}{l}\text { IoT Sensor } \\
\text { and Devices }\end{array}$ & 1 & 1 & 0.5 & 0 & 2.5 \\
\hline [90] & 2019 & Conference & $\begin{array}{l}\text { Proposed } \\
\text { System }\end{array}$ & $\begin{array}{l}\text { The idea of blockchain } \\
\text { innovation gives trust } \\
\text { among all the related nodes }\end{array}$ & $\begin{array}{l}\text { IoT Sensor } \\
\text { and Devices }\end{array}$ & 1 & 0.5 & & 0 & 1.5 \\
\hline
\end{tabular}




\begin{tabular}{|c|c|c|c|c|c|c|c|c|c|c|}
\hline Reference & Year & P. Channel & $\begin{array}{c}\text { Method of } \\
\text { Investigating }\end{array}$ & Primary Focus & Gadgets & $\mathbf{a}$ & $\mathbf{b}$ & c & d & Score \\
\hline [14] & 2019 & Conference & Architecture & $\begin{array}{l}\text { A blockchain design } \\
\text { committed to being } \\
\text { utilized in a supply chain } \\
\text { that involves distinctive } \\
\text { disseminated IoT elements }\end{array}$ & RFID & 1 & 1 & 0.5 & 0 & 2.5 \\
\hline [69] & 2019 & Conference & Guideline & $\begin{array}{l}\text { The combination of IoT } \\
\text { and Blockchain can create } \\
\text { elite Humantrain help } \\
\text { supply chains }\end{array}$ & No & 1 & 1 & 0.5 & 0 & 2.5 \\
\hline [92] & 2018 & Article & Tool & $\begin{array}{l}\text { Blockchain conveyed } \\
\text { record innovation to } \\
\text { advance and secure the } \\
\text { mind-boggling } \\
\text { programming and } \\
\text { equipment supply chain }\end{array}$ & No & 1 & 0.5 & & 0 & 2.5 \\
\hline [86] & 2019 & Conference & Implementation & $\begin{array}{c}\text { The role of IoT and } \\
\text { Blockchain in the digital } \\
\text { disruption of logistic and } \\
\text { supply chain }\end{array}$ & $\begin{array}{l}\text { IoT Sensor and } \\
\text { Devices, RFID }\end{array}$ & 1 & & 0.5 & 0 & 2 \\
\hline [74] & 2018 & Conference & Framework & $\begin{array}{l}\text { A fundamental system for } \\
\text { building a model or } \\
\text { recreation utilizing existing } \\
\text { technologies and protocols }\end{array}$ & $\begin{array}{l}\text { IoT Sensor } \\
\text { and Devices }\end{array}$ & 1 & 0.5 & & 0 & 2.5 \\
\hline [93] & 2019 & Conference & Guideline & $\begin{array}{l}\text { The Blockchain overcomes } \\
\text { the supply chain problems, } \\
\text { such as eliminating expired } \\
\text { food, equal distribution of } \\
\text { revenue, etc. }\end{array}$ & RFID & 1 & 0.5 & & 0 & 1.5 \\
\hline [70] & 2018 & Conference & Architecture & $\begin{array}{l}\text { A blockchain-based plan } \\
\text { for the unique ID of edge } \\
\text { contraptions through the } \\
\text { enlistment of hashed PUF } \\
\text { characteristics of a given } \\
\text { device at making. }\end{array}$ & $\begin{array}{l}\text { IoT Sensor } \\
\text { and Devices }\end{array}$ & 1 & 1 & 1 & 0 & 3 \\
\hline [78] & 2018 & Conference & Framework & $\begin{array}{l}\text { The writing is checked on } \\
\text { for structures and uses } \\
\text { cases that completely } \\
\text { understand Blockchain's } \\
\text { appropriateness past } \\
\text { money-related applications } \\
\text { and digital forms of money. }\end{array}$ & $\begin{array}{l}\text { IoT Sensor and Smart } \\
\text { Devices, Healthcare } \\
\text { Data Gateway (HGD), } \\
\text { Electronic Medical } \\
\text { Record (EMR) } \\
\text { systems, }\end{array}$ & 1 & 0.5 & 1 & 0 & 2.5 \\
\hline [46] & 2019 & Article & Architecture & $\begin{array}{l}\text { A blockchain enlivened } \\
\text { web of-things design for } \\
\text { making a straightforward } \\
\text { food supply chain. }\end{array}$ & RFID & 1 & 1 & 1 & 2 & 5 \\
\hline [14] & 2019 & Conference & Architecture & $\begin{array}{l}\text { A blockchain design } \\
\text { devoted to being utilized in } \\
\text { a graceful chain that } \\
\text { contains distinctive } \\
\text { circulated IoT elements. }\end{array}$ & RFID & 1 & 1 & 0.5 & 0 & 2.5 \\
\hline$[64]$ & 2019 & Conference & Implementation & $\begin{array}{l}\text { To execute, we presented } \\
\text { "Supplier Consumer } \\
\text { Network"—a hypothetical } \\
\text { start to finish food } \\
\text { detectability application. }\end{array}$ & $\begin{array}{l}\text { RFID technology, } \\
\text { HACCP }\end{array}$ & 1 & 0.5 & & 0 & 1.5 \\
\hline
\end{tabular}




\begin{tabular}{|c|c|c|c|c|c|c|c|c|c|c|}
\hline Reference & Year & P. Channel & $\begin{array}{c}\text { Method of } \\
\text { Investigating }\end{array}$ & Primary Focus & Gadgets & $\mathbf{a}$ & $\mathbf{b}$ & c & d & Score \\
\hline$[60]$ & 2017 & Conference & Guideline & $\begin{array}{l}\text { Blockchain-based } \\
\text { arrangements to diminish } \\
\text { organization, sparing } \\
\text { expenses, and utilized in } \\
\text { non-money-related } \\
\text { territories. }\end{array}$ & $\begin{array}{l}\text { IoT Sensor } \\
\text { and Devices }\end{array}$ & 1 & 0.5 & 51 & 0 & 2.5 \\
\hline [87] & 2019 & Conference & Guideline & $\begin{array}{l}\text { A decentralized calculated } \\
\text { and supply chain system to } \\
\text { cares for all offices and } \\
\text { elements of any association }\end{array}$ & $\begin{array}{l}\text { Smart sensors, IoT } \\
\text { devices, RFID }\end{array}$ & 1 & 1 & 0 & 0 & 2 \\
\hline [82] & 2019 & Conference & Architecture & $\begin{array}{l}\text { We proposed an } \\
\text { architecture coupled with a } \\
\text { non-volatile storage system } \\
\text { to give IoT information } \\
\text { preparing to supply chain }\end{array}$ & sensors, IoT devices & 1 & 0.5 & 0 & 0 & 1.5 \\
\hline$[71]$ & 2019 & Conference & framework & $\begin{array}{l}\text { A nonexclusive structure } \\
\text { for characterizing } \\
\text { granularity levels } \\
\text { dependent on the item's } \\
\text { one-of-a-kind attributes, } \\
\text { supply chain procedures, } \\
\text { and partners' commitment. }\end{array}$ & $\begin{array}{l}\text { Electronic Product } \\
\text { Code (EPC), RFID }\end{array}$ & 1 & 1 & 1 & 0 & 3 \\
\hline [67] & 2019 & Conference & Model & $\begin{array}{l}\text { The design principles of } \\
\text { the business model and } \\
\text { technical specifications to } \\
\text { work them }\end{array}$ & No & 1 & & 0.5 & 0 & 2 \\
\hline [72] & 2019 & Conference & $\begin{array}{l}\text { Proposed } \\
\text { System }\end{array}$ & $\begin{array}{l}\text { A tale approach for } \\
\text { forestalling such fake } \\
\text { copycat practices is } \\
\text { introduced. }\end{array}$ & No & 1 & & 50.5 & 0 & 2 \\
\hline [65] & 2020 & Article & architecture & $\begin{array}{l}\text { The engineering } \\
\text { incorporates Blockchain, } \\
\text { IoT, and colossal } \\
\text { information investigation } \\
\text { to permit venders to screen } \\
\text { the supply chain } \\
\text { productively and viably. }\end{array}$ & RFID & 1 & 1 & 0.5 & 2 & 4.5 \\
\hline [116] & 2020 & Article & $\begin{array}{l}\text { Proposed } \\
\text { System }\end{array}$ & $\begin{array}{l}\text { Proposes a pilot project to } \\
\text { create a cloud-based entry } \\
\text { for ongoing collaboration } \\
\text { and supply chain tracking. }\end{array}$ & $\begin{array}{l}\text { RFID, barcode, IoT } \\
\text { and Tracking devices }\end{array}$ & 1 & 0.5 & & 2 & 4.5 \\
\hline [91] & 2020 & Article & Implementation & $\begin{array}{c}\text { For Industrial IoT trustless } \\
\text { applications, the } \\
\text { implementation of a } \\
\text { moderate, stage logical } \\
\text { thinker, and stable } \\
\text { Blockchain tokenizer. }\end{array}$ & No & 1 & 1 & 0.5 & 2 & 4.5 \\
\hline [75] & 2020 & Article & Framework & $\begin{array}{l}\text { A blockchain structure and } \\
\text { its advancement forms are } \\
\text { introduced in detail, and } \\
\text { calculations for smart } \\
\text { contracts are produced for } \\
\text { the model usage. }\end{array}$ & No & 1 & 1 & 0.5 & 2 & 4.5 \\
\hline
\end{tabular}




\begin{tabular}{|c|c|c|c|c|c|c|c|c|c|c|}
\hline Reference & Year & P. Channel & $\begin{array}{c}\text { Method of } \\
\text { Investigating }\end{array}$ & Primary Focus & Gadgets & $\mathbf{a}$ & $\mathbf{b}$ & c & d & Score \\
\hline [83] & 2019 & Article & Guideline & $\begin{array}{l}\text { The exchange cost } \\
\text { hypothesis to make a } \\
\text { superior comprehension of } \\
\text { how Blockchain may } \\
\text { impact supply } \\
\text { chain relations }\end{array}$ & No & 1 & 0.5 & 1 & 2 & 4.5 \\
\hline [84] & 2020 & Article & Guideline & $\begin{array}{l}\text { The significant } \\
\text { ramifications of blockchain } \\
\text { innovation for tasks the } \\
\text { board emphasize the } \\
\text { dynamic procedures in the } \\
\text { supply chain the executives } \\
\text { from the point of view of } \\
\text { manageable execution. }\end{array}$ & No & 1 & 1 & 1 & 2 & 5 \\
\hline [81] & 2020 & Article & $\begin{array}{l}\text { Proposed } \\
\text { System }\end{array}$ & $\begin{array}{c}\text { A depiction of } \\
\text { bleeding-edge ideas from } \\
\text { start to finish; } \\
\text { 5G-empowered IoT fills in } \\
\text { as a spine for } \\
\text { Blockchain-based } \\
\text { mechanical robotization in } \\
\text { applications such as savvy } \\
\text { urban areas, brilliant } \\
\text { homes, medical services 4.0, } \\
\text { and shrewd agribusiness. }\end{array}$ & $\begin{array}{l}\text { RFID, NFC, IoT } \\
\text { devices (sensors) }\end{array}$ & 1 & 1 & 1 & 2 & 5 \\
\hline [80] & 2019 & Article & Guideline & $\begin{array}{l}\text { The progress in } \\
\text { deliberately examining the } \\
\text { worries identified with } \\
\text { disseminating and } \\
\text { appropriating } \\
\text { blockchain-based brilliant } \\
\text { agreements in the } \\
\text { humanitarian sector. }\end{array}$ & No & 1 & & 0.5 & 1 & 3 \\
\hline [88] & 2019 & Article & Guideline & $\begin{array}{l}\text { The strategic stage is } \\
\text { dependent on Blockchain } \\
\text { innovation ideas to tackle } \\
\text { supply chain issues with } \\
\text { disseminated } \\
\text { network nodes. }\end{array}$ & RFID & 1 & 1 & 0.5 & 0 & 2.5 \\
\hline
\end{tabular}

The chronicles of data sciences, supply chain, and essential advancements [66] 2020 Conference Guideline have been applied for bringing down cost and

RFID, sensors, GPS chips

$\begin{array}{lllll}1 & 1 & 0.5 & 0 & 2.5\end{array}$ facilitating security and accommodation

The ongoing state procurement and programmed stock of drug items to utilize IoT innovation and store RFID, sensors, QR codes $\begin{array}{llll}1 & 1 & 0 & 0\end{array}$ 2 information in a decentralized framework.

Proposes an IoT-based

[67] $2020 \quad$ Article $\quad$ Proposed
System
Barcodes, QR codes, GPRS. anticipation framework to handle the issue for safe cultivating. 


\begin{tabular}{|c|c|c|c|c|c|c|c|c|c|}
\hline Reference & Year & P. Channel & $\begin{array}{c}\text { Method of } \\
\text { Investigating }\end{array}$ & Primary Focus & Gadgets & a & b c c & d & Score \\
\hline [89] & 2019 & Conference & Guideline & $\begin{array}{c}\text { The essential attributes of } \\
\text { Blockchain include its use } \\
\text { in conveyance, } \\
\text { transportation, } \\
\text { partnerships, and } \\
\text { inventory networks and } \\
\text { how these main } \\
\text { characteristics are } \\
\text { implemented. }\end{array}$ & RFID & 1 & 0.51 & 0 & 2.5 \\
\hline [61] & 2019 & Article & Guideline & $\begin{array}{l}\text { Essential for finishing } \\
\text { prominence frameworks in } \\
\text { two exceptionally excellent } \\
\text { endeavors, cobalt mining } \\
\text { and drugs }\end{array}$ & No & 1 & 0.51 & 2 & 4.5 \\
\hline
\end{tabular}

\section{References}

1. Bucea-Manea-Țoniş, R.; Martins, O.M.D.; Bucea-Manea-T,oniş, R.; Gheorghiță, C.; Kuleto, V.; Ilić, M.P.; Simion, V.-E. Blockchain Technology Enhances Sustainable Higher Education. Sustainability 2021, 13, 12347. [CrossRef]

2. Punathumkandi, S.; Sundaram, V.M.; Panneer, P. Interoperable Permissioned-Blockchain with Sustainable Performance. Sustainability 2021, 13, 11132. [CrossRef]

3. Sharma, A.; Podoplelova, E.; Shapovalov, G.; Tselykh, A.; Tselykh, A. Sustainable Smart Cities: Convergence of Artificial Intelligence and Blockchain. Sustainability 2021, 13, 13076. [CrossRef]

4. Rehma, A.A.; Awan, M.J.; Butt, I. Comparison and Evaluation of Information Retrieval Models. VFAST Trans. Softw. Eng. 2018, 13, 7-14. [CrossRef]

5. Tyan, I.; Guevara-Plaza, A.; Yagüe, M.I. The Benefits of Blockchain Technology for Medical Tourism. Sustainability 2021, 13, 12448. [CrossRef]

6. Schletz, M.; Cardoso, A.; Dias, G.P.; Salomo, S. How Can Blockchain Technology Accelerate Energy Efficiency Interventions? A Use Case Comparison. Energies 2020, 13, 5869. [CrossRef]

7. Alam, T.M.; Awan, M.J. Domain analysis of information extraction techniques. Int. J. Multidiscip. Sci. Eng. 2018, 9, 1-9.

8. Wieland, A. Dancing the Supply Chain: Toward Transformative Supply Chain Management. J. Supply Chain Manag. 2020, 57, 58-73. [CrossRef]

9. Mentzer, J.T.; DeWitt, W.; Keebler, J.S.; Min, S.; Nix, N.W.; Smith, C.D.; Zacharia, Z.G. Defining Supply Chain Management. J. Bus. Logist. 2001, 22, 1-25. [CrossRef]

10. Aich, S.; Chakraborty, S.; Sain, M.; Lee, H.-I.; Kim, H.-C. A Review on Benefits of IoT Integrated Blockchain based Supply Chain Management Implementations across Different Sectors with Case Study. In Proceedings of the 21st International Conference on Advanced Communication Technology (ICACT), PyeongChang, Korea, 17-20 February 2019. [CrossRef]

11. Asamoah, D.; Agyei-Owusu, B.; Andoh-Baidoo, F.; Ayaburi, E. Inter-organizational systems use and supply chain performance: Mediating role of supply chain management capabilities. Int. J. Inf. Manag. 2020, 58, 102195. [CrossRef]

12. Birkel, H.; Müller, J. Potentials of industry 4.0 for supply chain management within the triple bottom line of sustainability-A systematic literature review. J. Supply Chain Manag. 2021, 289, 125612. [CrossRef]

13. Malik, S.; Dedeoglu, V.; Kanhere, S.S.; Jurdak, R. Trustchain: Trust management in Blockchain and iot supported supply chains. In Proceedings of the 2019 IEEE International Conference on Blockchain (Blockchain), Atlanta, GA, USA, 14-17 July 2019; pp. 184-193.

14. Awan, M.J.; Masood, O.A.; Mohammed, M.A.; Yasin, A.; Zain, A.M.; Damaševičius, R.; Abdulkareem, K.H. Image-Based Malware Classification Using VGG19 Network and Spatial Convolutional Attention. Electronics 2021, 10, 2444. [CrossRef]

15. Awan, M.J.; Farooq, U.; Babar, H.M.A.; Yasin, A.; Nobanee, H.; Hussain, M.; Hakeem, O.; Zain, A.M. Real-Time DDoS Attack Detection System Using Big Data Approach. Sustainability 2021, 13, 10743. [CrossRef]

16. Uddin, M.; Muzammal, M.; Hameed, M.K.; Javed, I.T.; Alamri, B.; Crespi, N. CBCIoT: A Consensus Algorithm for BlockchainBased IoT Applications. Appl. Sci. 2021, 11, 11011. [CrossRef]

17. Ali, Y.; Farooq, A.; Alam, T.M.; Farooq, M.S.; Awan, M.J.; Baig, T.I. Detection of Schistosomiasis Factors Using Association Rule Mining. IEEE Access 2019, 7, 186108-186114. [CrossRef]

18. Awan, M.J.; Bilal, M.H.; Yasin, A.; Nobanee, H.; Khan, N.S.; Zain, A.M. Detection of COVID-19 in Chest X-ray Images: A Big Data Enabled Deep Learning Approach. Int. J. Environ. Res. Public Health 2021, 18, 10147. [CrossRef] [PubMed]

19. Javed, R.; Saba, T.; Humdullah, S.; Jamail, N.S.M.; Awan, M.J. An Efficient Pattern Recognition Based Method for Drug-Drug Interaction Diagnosis. In Proceedings of the 1st International Conference on Artificial Intelligence and Data Analytics (CAIDA), Riyadh, Saudi Arabia, 6-7 April 2021; pp. 221-226. 
20. Nabeel, M.; Majeed, S.; Awan, M.J.; Ud-Din, H.M.; Wasique, M.; Nasir, R. Review on Effective Disease Prediction through Data Mining Techniques. Int. J. Electr. Eng. Inform. 2021, 13, 717-733. [CrossRef]

21. Gupta, M.; Jain, R.; Arora, S.; Gupta, A.; Awan, M.J.; Chaudhary, G.; Nobanee, H. AI-enabled COVID-9 Outbreak Analysis and Prediction: Indian States vs. Union Territories. Comput. Mater. Contin. 2021, 67, 933-950. [CrossRef]

22. Nagi, A.T.; Awan, M.J.; Javed, R.; Ayesha, N. A Comparison of Two-Stage Classifier Algorithm with Ensemble Techniques on Detection of Diabetic Retinopathy. In Proceedings of the 1st International Conference on Artificial Intelligence and Data Analytics (CAIDA), Riyadh, Saudi Arabia, 6-7 April 2021; pp. 212-215.

23. Vargas, H.; Lozano-Garzon, C.; Montoya, G.A.; Donoso, Y. Detection of Security Attacks in Industrial IoT Networks: A Blockchain and Machine Learning Approach. Electronics 2021, 10, 2662. [CrossRef]

24. Frikha, T.; Chaari, A.; Chaabane, F.; Cheikhrouhou, O.; Zaguia, A. Healthcare and Fitness Data Management Using the IoT-Based Blockchain Platform. J. Healthc. Eng. 2021, 2021, 9978863. [CrossRef] [PubMed]

25. Kouhizadeh, M.; Saberi, S.; Sarkis, J. Blockchain technology and the sustainable supply chain: Theoretically exploring adoption barriers. Int. J. Prod. Econ. 2020, 231, 107831. [CrossRef]

26. Ensor, A.; Schefer-Wenzl, S.; Miladinovic, I. Blockchains for iot payments: A survey. In Proceedings of the 2018 IEEE Globecom Workshops (GC Wkshps), Abu Dhabi, United Arab Emirates, 9-13 December 2018; pp. 1-6.

27. Zheng, X.R.; Lu, Y. Blockchain technology-recent research and future trend. Enterp. Inf. Syst. 2021. [CrossRef]

28. Abed, S.; Jaffal, R.; Mohd, B.J.; Al-Shayeji, M. An analysis and evaluation of lightweight hash functions for blockchain-based IoT devices. Clust. Comput. 2021, 24, 3065-3084. [CrossRef]

29. Bai, C.; Sarkis, J. A supply chain transparency and sustainability technology appraisal model for blockchain technology. Int. J. Prod. Res. 2020, 58, 2142-2162. [CrossRef]

30. Khan, A.G.; Zahid, A.H.; Hussain, M.; Riaz, U. Security of cryptocurrency using hardware wallet and qr code. In Proceedings of the 2019 International Conference on Innovative Computing (ICIC), Lahore, Pakistan, 1-2 November 2019; pp. 1-10.

31. Alam, T. Blockchain cities: The futuristic cities driven by Blockchain, big data and internet of things. GeoJournal 2021. [CrossRef]

32. Alfa, A.A.; Alhassan, J.K.; Olaniyi, O.M.; Olalere, M. Blockchain technology in IoT systems: Current trends, methodology, problems, applications, and future directions. J. Reliab. Intell. Environ. 2020, 7, 115-143. [CrossRef]

33. Sultan, A.; Mushtaq, M.A.; Abubakar, M. IOT security issues via Blockchain: A review paper. In Proceedings of the 2019 International Conference on Blockchain Technology, Honolulu, HI, USA, 15-18 March 2019; pp. 60-65.

34. Mehrban, S.; Khan, M.A.; Nadeem, M.W.; Hussain, M.; Ahmed, M.M.; Hakeem, O.; Saqib, S.; Kiah, M.L.M.; Abbas, F.; Hassan, M. Towards Secure FinTech: A Survey, Taxonomy, and Open Research Challenges. IEEE Access 2020, 8, 23391-23406. [CrossRef]

35. Aly, M.; Khomh, F.; Haoues, M.; Quintero, A.; Yacout, S. Enforcing security in Internet of Things frameworks: A Systematic Literature Review. Internet Things 2019, 6, 100050. [CrossRef]

36. Kouhizadeh, M.; Sarkis, J. Blockchain Practices, Potentials, and Perspectives in Greening Supply Chains. Sustainability 2018, 10, 3652. [CrossRef]

37. Delgado-Von-Eitzen, C.; Anido-Rifón, L.; Fernández-Iglesias, M. Application of Blockchain in Education: GDPR-Compliant and Scalable Certification and Verification of Academic Information. Appl. Sci. 2021, 11, 4537. [CrossRef]

38. Christidis, K.; Devetsikiotis, M. Blockchains and Smart Contracts for the Internet of Things. IEEE Access 2016, 4, $2292-2303$. [CrossRef]

39. Yeow, K.; Gani, A.; Ahmad, R.W.; Rodrigues, J.J.P.C.; Ko, K. Decentralized Consensus for Edge-Centric Internet of Things: A Review, Taxonomy, and Research Issues. IEEE Access 2017, 6, 1513-1524. [CrossRef]

40. Panarello, A.; Tapas, N.; Merlino, G.; Longo, F.; Puliafito, A. Blockchain and IoT Integration: A Systematic Survey. Sensors 2018, 18, 2575. [CrossRef] [PubMed]

41. Fernández-Caramés, T.M.; Fraga-Lamas, P. A Review on the Use of Blockchain for the Internet of Things. IEEE Access 2018, 6, 32979-33001. [CrossRef]

42. Khan, M.A.; Salah, K. IoT security: Review, blockchain solutions, and open challenges. Future Gener. Comput. 2018, 82, 395-411. [CrossRef]

43. Banerjee, M.; Lee, J.; Choo, K.-K.R. A blockchain future for internet of things security: A position paper. Digit. Commun. Networks 2018, 4, 149-160. [CrossRef]

44. Lohmer, J.; Bugert, N.; Lasch, R. Analysis of resilience strategies and ripple effect in blockchain-coordinated supply chains: An agent-based simulation study. Int. J. Prod. Econ. 2020, 228, 107882. [CrossRef]

45. Powell, W.; Foth, M.; Cao, S.; Natanelov, V. Garbage in garbage out: The precarious link between IoT and Blockchain in food supply chains. J. Ind. Inf. Integr. 2021. [CrossRef]

46. Song, Q.; Chen, Y.; Zhong, Y.; Lan, K.; Fong, S.; Tang, R. A Supply-chain System Framework Based on Internet of Things Using Blockchain Technology. ACM Trans. Internet Technol. 2021, 21, 1-24. [CrossRef]

47. Moosavi, J.; Naeni, L.M.; Fathollahi-Fard, A.M.; Fiore, U. Blockchain in supply chain management: A review, bibliometric, and network analysis. Environ. Sci. Pollut. Res. 2021. [CrossRef] [PubMed]

48. Zhu, X.N.; Peko, G.; Sundaram, D.; Piramuthu, S. Blockchain-Based Agile Supply Chain Framework with IoT. Inf. Syst. Front. 2021. [CrossRef] 
49. Hussain, M.; Nadeem, M.W.; Iqbal, S.; Mehrban, S.; Fatima, S.N.; Hakeem, O.; Mustafa, G. Security and Privacy in FinTech: A Policy Enforcement Framework. In Research Anthology on Concepts, Applications, and Challenges of FinTech; IGI Global: Hershey, PA, USA, 2021; pp. 372-384.

50. Mistry, I.; Tanwar, S.; Tyagi, S.; Kumar, N. Blockchain for 5G-enabled IoT for industrial automation: A systematic review, solutions, and challenges. Mech. Syst. Signal Process. 2019, 135, 106382. [CrossRef]

51. Rožman, N.; Vrabič, R.; Corn, M.; Požrl, T.; Diaci, J. Distributed logistics platform based on Blockchain and IoT. Procedia CIRP 2019, 81, 826-831. [CrossRef]

52. Ali, S.F.; Aslam, A.S.; Awan, M.J.; Yasin, A.; Damaševičius, R. Pose Estimation of Driver's Head Panning Based on Interpolation and Motion Vectors under a Boosting Framework. Appl. Sci. 2021, 11, 11600. [CrossRef]

53. Rafique, I.; Fatima, K.; Dastagir, A.; Mahmood, S.; Hussain, M. Autism Identification and Learning Through Motor Gesture Patterns. In Proceedings of the 2019 International Conference on Innovative Computing (ICIC), Lahore, Pakistan, 1-2 November 2019; pp. 1-7.

54. Terzi, S.; Zacharaki, A.; Nizamis, A.; Votis, K.; Ioannidis, D.; Tzovaras, D.; Stamelos, I. Transforming the supply-chain management and industry logistics with blockchain smart contracts. In Proceedings of the 23rd Pan-Hellenic Conference on Informatics, Nicosia, Cyprus, 28-30 November 2019; pp. 9-14. [CrossRef]

55. Queiroz, M.M.; Telles, R.; Bonilla, S.H. Blockchain and supply chain management integration: A systematic review of the literature. Supply Chain Manag. Int. J. 2019, 25, 241-254. [CrossRef]

56. Attique, M.; Farooq, M.S.; Khelifi, A.; Abid, A. Prediction of Therapeutic Peptides Using Machine Learning: Computational Models, Datasets, and Feature Encodings. IEEE Access 2020, 8, 148570-148594. [CrossRef]

57. Shi, J.; Yi, D.; Kuang, J. Pharmaceutical Supply Chain Management System with Integration of IoT and Blockchain Technology. In Smart Blockchain; SmartBlock 2019. Lecture Notes in Computer Science; Qiu, M., Ed.; Springer: Cham, Switzerland, 2019; pp. 97-108. [CrossRef]

58. Bocek, T.; Rodrigues, B.B.; Strasser, T.; Stiller, B. Blockchains everywhere-a use-case of blockchains in the pharma supply-chain. In Proceedings of the 2017 IFIP/IEEE symposium on integrated network and service management (IM), Lisbon, Portugal, 8-12 May 2017; pp. 772-777.

59. Madumidha, S.; Ranjani, P.S.; Varsinee, S.S.; Sundari, P. Transparency and Traceability: In Food Supply Chain System using Blockchain Technology with Internet of Things. In Proceedings of the 3rd International Conference on Trends in Electronics and Informatics (ICOEI), Tirunelveli, India, 23-25 April 2019. [CrossRef]

60. Moudoud, H.; Cherkaoui, S.; Khoukhi, L. An IoT Blockchain Architecture Using Oracles and Smart Contracts: The Use-Case of a Food Supply Chain. In Proceedings of the 30th Annual International Symposium on Personal, Indoor and Mobile Radio Communications (PIMRC), Istanbul, Turkey, 8-11 September 2019; pp. 1-6. [CrossRef]

61. Tsang, Y.; Choy, K.L.; Wu, C.H.; Ho, G.T.S.; Lam, H. Blockchain-Driven IoT for Food Traceability with an Integrated Consensus Mechanism. IEEE Access 2019, 7, 129000-129017. [CrossRef]

62. Arena, A.; Bianchini, A.; Perazzo, P.; Vallati, C.; Dini, G. BRUSCHETTA: An IoT Blockchain-Based Framework for Certifying Extra Virgin Olive Oil Supply Chain. In Proceedings of the IEEE International Conference on Smart Computing (SMARTCOMP), Washington, DC, USA, 12-15 June 2019; pp. 173-179. [CrossRef]

63. Khan, N.S.; Abid, A.; Abid, K.; Farooq, U.; Farooq, M.S.; Jameel, H. Speak Pakistan: Challenges in developing Pakistan sign language using information technology. South Asian Stud. 2020, 30, 2.

64. Tian, F. An Information System for Food Safety Monitoring in Supply Chains based on HACCP, Blockchain and Internet of things. Ph.D. Thesis, WU Vienna University of Economics and Business, Wien, Austira, 2018.

65. Madumidha, S.; Ranjani, P.S.; Vandhana, U.; Venmuhilan, B. A theoretical implementation: Agriculture-food supply chain management using blockchain technology. In Proceedings of the 2019 TEQIP III Sponsored International Conference on Microwave Integrated Circuits, Photonics and Wireless Networks (IMICPW), Tiruchirappalli, India, 22-24 May 2019; pp. 174-178.

66. Iqbal, R.; Butt, T.A. Safe farming as a service of blockchain-based supply chain management for improved transparency. Clust. Comput. 2020, 23, 2139-2150. [CrossRef]

67. Kim, M.; Hilton, B.; Burks, Z.; Reyes, J. Integrating blockchain, smart contract-tokens, and IoT to design a food traceability solution. In Proceedings of the IEEE 9th Annual Information Technology, Electronics and Mobile Communication Conference (IEMCON), Vancouver, BC, Canada, 1-8 November 2018; pp. 335-340.

68. Jayaraman, R.; Salah, K.; King, N.; Saleh, K. Improving Opportunities in Healthcare Supply Chain Processes via the Internet of Things and Blockchain Technology. Int. J. Health Inf. Syst. Inform. 2019, 14, 49-65. [CrossRef]

69. Anam, M.; Ponnusamy, V.A.; Hussain, M.; Nadeem, M.W.; Javed, M.; Goh, H.G.; Qadeer, S. Osteoporosis Prediction for Trabecular Bone using Machine Learning: A Review. Comput. Mater. Contin. 2021, 67, 89-105. [CrossRef]

70. Awan, M.; Rahim, M.; Salim, N.; Ismail, A.; Shabbir, H. Acceleration of knee MRI cancellous bone classification on google colaboratory using convolutional neural network. Int. J. Adv. Trends Comput. Sci. 2019, 8, 83-88. [CrossRef]

71. Childerhouse, P.; Hermiz, R.; Mason-Jones, R.; Popp, A.; Towill, D.R. Information flow in automotive supply chains-present industrial practice. Ind. Manag. Data Syst. 2003, 103, 491-502. [CrossRef]

72. Awan, M.J.; Yasin, A.; Nobanee, H.; Ali, A.A.; Shahzad, Z.; Nabeel, M.; Zain, A.M.; Shahzad, H.M.F. Fake News Data Exploration and Analytics. Electronics 2021, 10, 2326. [CrossRef] 
73. Lu, D.; Moreno-Sanchez, P.; Mitra, P.; Feldman, K.; Fodale, J.; Kosofsky, J.; Kate, A. Toward Privacy-Aware Traceability for Automotive Supply Chains. SAE Int. J. Transp. Cybersecur. Priv. 2021, 4. [CrossRef]

74. Lohmer, J.; Lasch, R. Blockchain in operations management and manufacturing: Potential and barriers. Comput. Ind. Eng. 2020, 149, 106789. [CrossRef]

75. Wang, Z.; Wang, T.; Hu, H.; Gong, J.; Ren, X.; Xiao, Q. Blockchain-based framework for improving supply chain traceability and information sharing in precast construction. Autom. Constr. 2019, 111, 103063. [CrossRef]

76. Dubey, R.; Gunasekaran, A.; Bryde, D.J.; Dwivedi, Y.K.; Papadopoulos, T. Blockchain technology for enhancing swift-trust, collaboration and resilience within a humanitarian supply chain setting. Int. J. Prod. Res. 2020, 58, 3381-3398. [CrossRef]

77. Patil, A.; Shardeo, V.; Dwivedi, A.; Madaan, J. An integrated approach to model the blockchain implementation barriers in humanitarian supply chain. J. Glob. Oper. Strateg. Sourc. 2020, 14, 81-103. [CrossRef]

78. Min, H. Blockchain technology for enhancing supply chain resilience. Bus. Horiz. 2019, 62, 35-45. [CrossRef]

79. Khatoon, A.; Verma, P.; Southernwood, J.; Massey, B.; Corcoran, P. Blockchain in energy efficiency: Potential applications and benefits. Energies 2019, 12, 3317. [CrossRef]

80. Demir, M.; Turetken, O.; Ferwom, A. Blockchain and IoT for delivery assurance on supply chain (BIDAS). In Proceedings of the IEEE International Conference on Big Data (Big Data), Los Angeles, CA, USA, 9-12 December 2019; pp. 5213-5222.

81. Rao, A.R.; Clarke, D. Perspectives on emerging directions in using IoT devices in blockchain applications. Internet Things 2020, 10, 100079. [CrossRef]

82. Lee, Z.E.; Chua, R.L.H.; Keoh, S.L.; Ohba, Y. Performance Evaluation of Big Data Processing at the Edge for IoT-Blockchain Applications. In Proceedings of the 2019 IEEE Global Communications Conference (GLOBECOM), Waikoloa, HI, USA, 9-13 December 2019; pp. 1-6.

83. Wang, S.; Qu, X. Blockchain applications in shipping, transportation, logistics, and supply chain. In Smart Transportation Systems 2019; Springer: Singapore, 2019; pp. 225-231.

84. Müller, M.; Garzon, S.R.; Westerkamp, M.; Lux, Z.A. HIDALS: A Hybrid IoT-based Decentralized Application for Logistics and Supply Chain Management. In Proceedings of the 2019 IEEE 10th Annual Information Technology, Electronics and Mobile Communication Conference (IEMCON), Vancouver, BC, Canada, 17-19 October 2019; pp. 802-808.

85. Pervez, H.; Haq, I.U. Blockchain and IoT based disruption in logistics. In Proceedings of the 2nd International Conference on Communication, Computing and Digital Systems (C-CODE), Islamabad, Pakistan, 6-7 March 2019; pp. $276-281$.

86. Tan, B.Q.; Wang, F.; Liu, J.; Kang, K.; Costa, F. A Blockchain-Based Framework for Green Logistics in Supply Chains. Sustainability 2020, 12, 4656. [CrossRef]

87. Abubakar, A.I.; Omeke, K.G.; Ozturk, M.; Hussain, S.; Imran, M.A. The role of artificial intelligence driven 5G networks in COVID-19 outbreak: Opportunities, challenges, and future outlook. Front. Commun. Netw. 2020, 1, 4. [CrossRef]

88. Mastos, T.D.; Nizamis, A.; Terzi, S.; Gkortzis, D.; Papadopoulos, A.; Tsagkalidis, N.; Ioannidis, D.; Votis, K.; Tzovaras, D. Introducing an application of an industry 4.0 solution for circular supply chain management. J. Clean. Prod. 2021, $300,126886$. [CrossRef]

89. Iqbal, S.; Hussain, M.; Munir, M.U.; Hussain, Z.; Mehrban, S.; Ashraf, M.A. Crypto-Currency: Future of FinTech. In Research Anthology on Blockchain Technology in Business, Healthcare, Education, and Government; IGI Global: Hershey, PA, USA, 2021; pp. 1915-1924.

90. Helo, P.; Shamsuzzoha, A. Real-time supply chain-A blockchain architecture for project deliveries. Robot. Comput. Manuf. 2019, 63, 101909. [CrossRef]

91. Schmidt, C.G.; Wagner, S.M. Blockchain and supply chain relations: A transaction cost theory perspective. J. Purch. Supply Manag. 2019, 25, 100552. [CrossRef]

92. Idrees, S.; Nowostawski, M.; Jameel, R.; Mourya, A. Security Aspects of Blockchain Technology Intended for Industrial Applications. Electronics 2021, 10, 951. [CrossRef]

93. Ghazal, T.M.; Anam, M.; Hasan, M.K.; Hussain, M.; Farooq, M.S.; Ali, H.M.A.; Ahmad, M.; Soomro, T.R. Hep-Pred: Hepatitis C Staging Prediction Using Fine Gaussian SVM. Comput. Mater. Contin. 2021, 69, 191-203. [CrossRef]

94. Ferooz, F.; Hassan, M.T.; Awan, M.J.; Nobanee, H.; Kamal, M.; Yasin, A.; Zain, A.M. Suicide Bomb Attack Identification and Analytics through Data Mining Techniques. Electronics 2021, 10, 2398. [CrossRef]

95. Cole, R.; Stevenson, M.; Aitken, J. Blockchain technology: Implications for operations and supply chain management. Supply Chain Manag. Int. J. 2019, 24, 469-483. [CrossRef]

96. Mylrea, M.; Gourisetti, S.N.G. Blockchain for supply chain cybersecurity, optimization and compliance. In Proceedings of the 2018 Resilience Week (RWS), Denver, CO, USA, 20-23 August 2018; pp. 70-76.

97. Hussain, M.; Al-Haiqi, A.; Zaidan, A.; Zaidan, B.; Kiah, M.M.; Anuar, N.B.; Abdulnabi, M. The rise of keyloggers on smartphones: A survey and insight into motion-based tap inference attacks. Pervasive Mob. Comput. 2016, 25, 1-25. [CrossRef]

98. Hussain, M.; Zaidan, A.; Zidan, B.; Iqbal, S.; Ahmed, M.; Albahri, O.S. Conceptual framework for the security of mobile health applications on Android platform. Telemat. Inform. 2018, 35, 1335-1354. [CrossRef]

99. Kiah, M.L.M.; Al-Bakri, S.H.; Zaidan, A.A.; Zaidan, B.B.; Hussain, M. Design and Develop a Video Conferencing Framework for Real-Time Telemedicine Applications Using Secure Group-Based Communication Architecture. J. Med. Syst. 2014, $38,133$. [CrossRef] [PubMed] 
100. Pundir, A.K.; Jagannath, J.D.; Chakraborty, M.; Ganpathy, L. Technology Integration for Improved Performance: A Case Study in Digitization of Supply Chain with Integration of Internet of Things and Blockchain Technology. In Proceedings of the 9th Annual Computing and Communication Workshop and Conference (CCWC), Las Vegas, NV, USA, 7-9 January 2019; pp. 0170-0176. [CrossRef]

101. Negka, L.; Gketsios, G.; Anagnostopoulos, N.A.; Spathoulas, G.; Kakarountas, A.; Katzenbeisser, S. Employing blockchain and physical unclonable functions for counterfeit IoT devices detection. In Proceedings of the International Conference on Omni-Layer Intelligent Systems, Crete, Greece, 5-7 May 2019; pp. 172-178.

102. Kumar, M.S.; Vimal, S.; Jhanjhi, N.; Dhanabalan, S.S.; Alhumyani, H.A. Blockchain based peer to peer communication in autonomous drone operation. Energy Rep. 2021, 7, 7925-7939. [CrossRef]

103. Mondal, S.; Wijewardena, K.P.; Karuppuswami, S.; Kriti, N.; Kumar, D.; Chahal, P. Blockchain Inspired RFID-Based Information Architecture for Food Supply Chain. IEEE Internet Things J. 2019, 6, 5803-5813. [CrossRef]

104. Abdulnabi, M.; Al-Haiqi, A.; Kiah, M.; Zaidan, A.; Zaidan, B.; Hussain, M. A distributed framework for health information exchange using smartphone technologies. J. Biomed. Inform. 2017, 69, 230-250. [CrossRef]

105. Dey, S.; Saha, S.; Singh, A.K.; McDonald-Maier, K. FoodSQRBlock: Digitizing Food Production and the Supply Chain with Blockchain and QR Code in the Cloud. Sustainability 2021, 13, 3486. [CrossRef]

106. Singh, R.; Dwivedi, A.D.; Srivastava, G. Internet of things based blockchain for temperature monitoring and counterfeit pharmaceutical prevention. Sensors 2020, 20, 3951. [CrossRef] [PubMed]

107. Kalid, N.; Zaidan, A.A.; Zaidan, B.B.; Salman, O.; Hashim, M.; Muzammil, H. Based Real Time Remote Health Monitoring Systems: A Review on Patients Prioritization and Related "Big Data" Using Body Sensors information and Communication Technology. J. Med. Syst. 2017, 42, 30. [CrossRef] [PubMed]

108. Yue, X.; Wang, H.; Jin, D.; Li, M.; Jiang, W. Healthcare data gateways: Found healthcare intelligence on blockchain with novel privacy risk control. J. Med Syst. 2016, 40, 218. [CrossRef]

109. Faheem, M.R.; Anees, T.; Hussain, M. The Web of Things: Findability Taxonomy and Challenges. IEEE Access 2019, 7, 185028-185041. [CrossRef]

110. Zaidan, B.B.; Al-Haiqi, A.; Zaidan, A.A.; Abdulnabi, M.; Kiah, M.L.M.; Muzamel, H. A Security Framework for Nationwide Health Information Exchange based on Telehealth Strategy. J. Med. Syst. 2015, 39, 51. [CrossRef] [PubMed]

111. Zaidan, A.; Zaidan, B.; Hussain, M.; Al-Haiqi, A.; Kiah, M.M.; Abdulnabi, M. Multi-criteria analysis for OS-EMR software selection problem: A comparative study. Decis. Support Syst. 2015, 78, 15-27. [CrossRef]

112. Zaidan, A.; Zaidan, B.; Al-Haiqi, A.; Kiah, M.; Hussain, M.; Abdulnabi, M. Evaluation and selection of open-source EMR software packages based on integrated AHP and TOPSIS. J. Biomed. Inform. 2015, 53, 390-404. [CrossRef] [PubMed]

113. Hussain, M.; Al-Haiqi, A.; Zaidan, A.; Zaidan, B.; Kiah, M.; Anuar, N.B.; Abdulnabi, M. The landscape of research on smartphone medical apps: Coherent taxonomy, motivations, open challenges and recommendations. Comput. Methods Programs Biomed. 2015, 122, 393-408. [CrossRef] [PubMed]

114. Hussain, M.; Al-Haiqi, A.; Zaidan, A.; Zaidan, B.; Kiah, M.; Iqbal, S.; Abdulnabi, M. A security framework for mHealth apps on Android platform. Comput. Secur. 2018, 75, 191-217. [CrossRef]

115. Haider, A.; Khan, M.; Hussain, M. ECG images dataset of cardiac and COVID-19 patients. (Special Issue: COVID-19 data). Data Brief 2021, 34, 106762.

116. Iqbal, S.; Kiah, M.L.M.; Dhaghighi, B.; Hussain, M.; Khan, S.; Khan, M.K.; Choo, K.-K.R. On cloud security attacks: A taxonomy and intrusion detection and prevention as a service. J. Netw. Comput. Appl. 2016, 74, 98-120. [CrossRef]

117. Caro, M.P.; Ali, M.S.; Vecchio, M.; Giaffreda, R. Blockchain-based traceability in Agri-Food supply chain management: A practical implementation. In Proceedings of the 2018 IoT Vertical and Topical Summit on Agriculture-Tuscany (IOT Tuscany), Tuscany, Italy, 8-9 May 2018; pp. 1-4.

118. Azzi, R.; Chamoun, R.K.; Sokhn, M. The power of a blockchain-based supply chain. Comput. Ind. Eng. 2019, 135, 582-592. [CrossRef]

119. Awan, M.J.; Rahim, M.S.M.; Nobanee, H.; Yasin, A.; Khalaf, O.I.; Ishfaq, U. A Big Data Approach to Black Friday Sales. Intell. Autom. Soft Comput. 2021, 27, 785-797. [CrossRef]

120. Awan, M.J.; Khan, M.A.; Ansari, Z.K.; Yasin, A.; Shehzad, H.M.F. Fake profile recognition using big data analytics in social media platforms. Int. J. Comput. Appl. Technol. 2021, in press.

121. Awan, M.J.; Gilani, S.A.H.; Ramzan, H.; Nobanee, H.; Yasin, A.; Zain, A.M.; Javed, R. Cricket Match Analytics Using the Big Data Approach. Electronics 2021, 10, 2350. [CrossRef]

122. Awan, M.J.; Rahim, M.S.M.; Nobanee, H.; Munawar, A.; Yasin, A.; Azlanmz, A.M.Z. Social Media and Stock Market Prediction: A Big Data Approach. Comput. Mater. Contin. 2021, 67, 2569-2583. [CrossRef]

123. Khalil, A.; Awan, M.J.; Yasin, A.; Singh, V.P.; Shehzad, H.M.F. Flight Web Searches Analytics through Big Data. Int. J. Comput. Appl. Technol. 2021, in press.

124. Ahmed, H.M.; Javed Awan, M.; Khan, N.S.; Yasin, A.; Faisal Shehzad, H.M. Sentiment Analysis of Online Food Reviews using Big Data Analytics. Elem. Educ. Online 2021, 20, 827-836.

125. Awan, M.; Khan, R.; Nobanee, H.; Yasin, A.; Anwar, S.; Naseem, U.; Singh, V. A Recommendation Engine for Predicting Movie Ratings Using a Big Data Approach. Electronics 2021, 10, 1215. [CrossRef] 
126. Aftab, M.O.; Awan, M.J.; Khalid, S.; Javed, R.; Shabir, H. Executing Spark BigDL for Leukemia Detection from Microscopic Images using Transfer Learning. In Proceedings of the 1st International Conference on Artificial Intelligence and Data Analytics (CAIDA), Riyadh, Saudi Arabia, 6-7 April 2021; pp. 216-220.

127. Yuksel, M.E. Design and Implementation of a Batteryless Wireless Embedded System for IoT Applications. Electrica 2019, $19,1-11$. [CrossRef]

128. Awan, M.J.; Rahim, M.M.; Salim, N.; Mohammed, M.; Garcia-Zapirain, B.; Abdulkareem, K. Efficient Detection of Knee Anterior Cruciate Ligament from Magnetic Resonance Imaging Using Deep Learning Approach. Diagnostics 2021, 11, 105. [CrossRef]

129. Nadeem, M.W.; Al Ghamdi, M.A.; Hussain, M.; Khan, M.A.; Khan, K.M.; AlMotiri, S.H.; Butt, S.A. Brain Tumor Analysis Empowered with Deep Learning: A Review, Taxonomy, and Future Challenges. Brain Sci. 2020, 10, 118. [CrossRef]

130. Awan, M.J.; Raza, A.; Yasin, A.; Shehzad, H.M.F.; Butt, I. The Customized Convolutional Neural Network of Face Emotion Expression Classification. Ann. Rom. Soc. Cell Biol. 2021, 25, 5296-5304.

131. Mujahid, A.; Awan, M.; Yasin, A.; Mohammed, M.; Damaševičius, R.; Maskeliūnas, R.; Abdulkareem, K. Real-Time Hand Gesture Recognition Based on Deep Learning YOLOv3 Model. Appl. Sci. 2021, 11, 4164. [CrossRef]

132. Mubashar, R.; Javed Awan, M.; Ahsan, M.; Yasin, A.; Partab Singh, V. Efficient residential load forecasting using deep learning approach. Int. J. Comput. Appl. Technol. 2021, in press.

133. Awan, M.J.; Rahim, M.S.M.; Salim, N.; Rehman, A.; Nobanee, H.; Shabir, H. Improved Deep Convolutional Neural Network to Classify Osteoarthritis from Anterior Cruciate Ligament Tear Using Magnetic Resonance Imaging. J. Pers. Med. 2021, 11, 1163. [CrossRef] [PubMed]

134. Nadeem, M.W.; Goh, H.G.; Ali, A.; Hussain, M.; Khan, M.A.; Ponnusamy, V.A. Bone Age Assessment Empowered with Deep Learning: A Survey, Open Research Challenges and Future Directions. Diagnostics 2020, 10, 781. [CrossRef]

135. Abdullah, A.; Awan, M.; Shehzad, M.; Ashraf, M. Fake news classification bimodal using convolutional neural network and long short-term memory. Int. J. Emerg. Technol. 2020, 11, 209-212. 